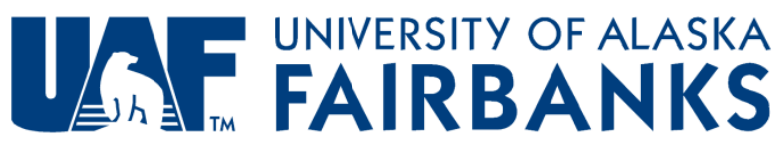

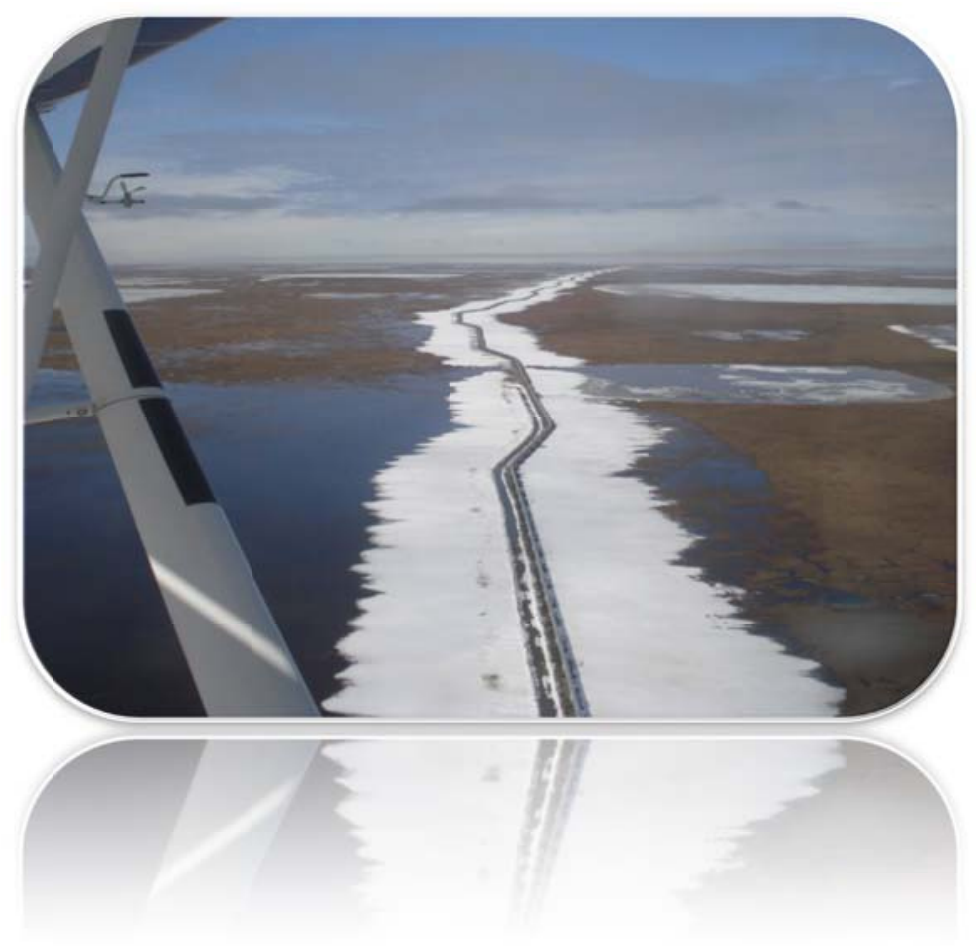

\section{Using Snow Fences to Augment Fresh Water Supplies in Shallow Arctic Lakes}

Final Report, September 2013, DE - NT0005684 
Report Title: Using Snow Fences to Augment Fresh Water Supplies in Shallow Arctic Lakes

Type of Report: Final Scientific/Technical Report

Reporting Period Start Date: October 2008

Reporting Period End Date: March 2013

Principal Author: Svetlana L. Stuefer

Date Report Was Issued: September 2013

DOE Award Number: DE - NT0005684

Title page picture caption: The Alyeska oil pipeline seen from an altitude of 500 feet about 20 miles south of Prudhoe Bay. The pipeline acts as a snow fence, retaining more snow than the surrounding tundra.

Name and Address of Submitting Organization:

University of Alaska Fairbanks, Institute of Northern Engineering, Water and Environmental Research Center, 306

Tanana Drive, Fairbanks AK 99775-5860, USA

Name and Address of Collaborating Organizations:

Department of the Army, Engineer Research and Development Center, Corps of Engineers, Cold Region Research and Engineering Laboratory, PO Box 35170, Fort Wainwright, AK 99703-0170, USA

Colorado State University, Cooperative Institute for Research in the Atmosphere, 1375 Campus Delivery, Fort Collins, CO 80523-1375, USA

Report number: INE/WERC 13.06

Recommended citation:

Stuefer S.L., Kane D.L., 2013. Using snow fences to augment fresh water supplies in shallow arctic lakes. University of Alaska Fairbanks, Water and Environmental Research Center, Report INE/WERC 13.06, September 2013, Fairbanks, Alaska, USA, 32 pp. 


\section{Disclaimer}

This report was prepared as an account of work sponsored by an agency of the United States Government. Neither the United States Government nor any agency thereof, nor any of their employees, makes any warranty, express or implied, or assumes any legal liability or responsibility for the accuracy, completeness, or usefulness of any information, apparatus, product, or process disclosed, or represents that its use would not infringe privately owned rights. Reference herein to any specific commercial product, process, or service by trade name, trademark, manufacturer, or otherwise does not necessarily constitute or imply its endorsement, recommendation, or favoring by the United States Government or any agency thereof. The views and opinions of authors expressed herein do not necessarily state or reflect those of the United States Government or any agency thereof. 


\section{Acknowledgments}

This report is based on work conducted under Award DE-NT0005684 issued by the U.S. Department of Energy, National Energy Technology Laboratory. The Alaska Department of Transportation and Public Facilities supported this work by sharing water-use data during the years of the experiments.

Colleagues and students from the Water and Environmental Research Center contributed to the data collection. Ken Irving, Emily Youcha, and Glenn Scott helped initiate field data collection. Special thanks are expressed to Joel Bailey for his work in the field and on data analysis throughout the progress of this work. Natalia Kulchitsky provided structural analysis of the snow fences. Sandra McSurdy, NETL project manager, oversaw the project work and provided important administrative insight necessary for successful project implementation. The project greatly benefited from collaboration with Matthew Sturm (UAF), Arthur Gelvin (CRREL), Christopher Heimstra (CRREL), Stephanie Saari (CRREL), and Glen Liston (CSU). 


\section{Abstract}

This project was funded by the U.S. Department of Energy, National Energy Technology Laboratory (NETL) to address environmental research questions specifically related to Alaska's oil and gas natural resources development. The focus of this project was on the environmental issues associated with allocation of water resources for construction of ice roads and ice pads. Earlier NETL projects showed that oil and gas exploration activities in the U.S. Arctic require large amounts of water for ice road and ice pad construction. Traditionally, lakes have been the source of freshwater for this purpose. The distinctive hydrological regime of northern lakes, caused by the presence of ice cover and permafrost, exerts influence on lake water availability in winter. Lakes are covered with ice from October to June, and there is often no water recharge of lakes until snowmelt in early June. After snowmelt, water volumes in the lakes decrease throughout the summer, when water loss due to evaporation is considerably greater than water gained from rainfall. This balance switches in August, when air temperature drops, evaporation decreases, and rain (or snow) is more likely to occur. Some of the summer surface storage deficit in the active layer and surface water bodies (lakes, ponds, wetlands) is recharged during this time. However, if the surface storage deficit is not replenished (for example, precipitation in the fall is low and near-surface soils are dry), lake recharge is directly affected, and water availability for the following winter is reduced.

In this study, we used snow fences to augment fresh water supplies in shallow arctic lakes despite unfavorable natural conditions. We implemented snow-control practices to enhance snowdrift accumulation (greater snow water equivalent), which led to increased meltwater production and an extended melting season that resulted in lake recharge despite low precipitation during the years of the experiment. For three years (2009, 2010, and 2011), we selected and monitored two lakes with similar hydrological regimes. Both lakes are located 30 miles south of Prudhoe Bay, Alaska, near Franklin Bluffs. One is an experimental lake, where we installed a snow fence; the other is a control lake, where the natural regime was preserved. The general approach was to compare the hydrologic response of the lake to the snowdrift during the summers of 2010 and 2011 against the "baseline" conditions in 2009. Highlights of the project included new data on snow transport rates on the Alaska North Slope, an evaluation of the experimental lake's hydrological response to snowdrift melt, and cost assessment of snowdrift-generated water. High snow transport rates $(0.49 \mathrm{~kg} / \mathrm{s} / \mathrm{m})$ ensured that the snowdrift reached its equilibrium profile by winter's end. Generally, natural snowpack disappeared by the beginning of June in this area. In contrast, snow in the drift lasted through early July, supplying the experimental lake with snowmelt when water in other tundra lakes was decreasing. The experimental lake retained elevated water levels during the entire open-water season. Comparison of lake water volumes during the experiment against the baseline year showed that, by the end of summer, the drift generated by the snow fence had increased lake water volume by at least $21-29 \%$. We estimated water cost at 1.9 cents per gallon during the first year and 0.8 cents per gallon during the second year. This estimate depends on the cost of snow fence construction in remote arctic locations, which we assumed to be at $\$ 7.66$ per square foot of snow fence frontal area. The snow fence technique was effective in augmenting the supply of lake water during summers 2010 and 2011 despite low rainfall during both summers. Snow fences are a simple, yet an effective, way to replenish tundra lakes with freshwater and increase water availability in winter.

This research project was synergetic with the NETL project, "North Slope Decision Support System (NSDSS) for Water Resources Planning and Management." The results of these projects were implemented in the NSDSS model and added to the annual water budget. This implementation allows one to account for snowdrift contributions during ice road planning with the NSDSS and assists with mitigating those risks associated with potentially unfavorable climate and hydrological conditions (that is, surface storage deficit and/or low precipitation). 


\section{Executive Summary}

The arctic region of the United States is covered by snow up to nine months of the year. People who routinely work in this environment are affected in many ways by the prolonged presence of snow. Blowing snow reduces visibility, and snowdrifts block roadways and hamper egress from and ingress to buildings. At the same time, the presence of snow serves as insulation, restricting energy loss from vegetation and soils; as a water supply for wildlife, humans, and industry; and as a foundation material for snow and ice roads that protect the tundra from overland travel.

Earlier NETL projects showed that oil and gas exploration activities require large amounts of water for ice roads and ice pad construction (Hinzman et al., 2006). Traditionally, water is acquired from tundra lakes, as local streams and rivers have very low winter flow. These lakes are covered by ice from October to June, and recharged by snowmelt in early June. After snowmelt is complete, lakes, ponds, and soils start drying out during the summer, potentially causing surface storage water deficits. Some of this summer surface storage deficit can be offset in August and September prior to freeze-up by enhanced precipitation. However, if the surface storage deficit is not completely replenished (for example, if precipitation in the fall is low and/or near-surface soil is dry), lake recharge is directly affected, and water availability for the following winter is reduced. Continuous permafrost and the shallow active layer generally limit both subpermafrost and suprapermafrost groundwater contributions to these hydrologic systems.

Low annual precipitation and long periods of continuous freezing temperatures combine to make rational management of water resources challenging in this remote yet natural resource-rich region of the United States. Our current understanding of hydrologic processes that form the basis for water resource management is still limited by sparse observational networks, poor data quality, and relatively short periods of record in the Arctic. These limitations constitute a significant challenge for federal and state land-management agencies that are required to use their best judgment in considering requests for water use and tundra travel permits in the Arctic. In response to this challenge, an extensive study of tundra lakes was conducted by the University of Alaska Fairbanks and Geo-Watersheds Scientific under the DOE award "North Slope Hydrology, Water Use, and Management Tools, 2002-2008." This study of winter water use of tundra lakes provided invaluable information on physical and chemical characteristics of the lakes. One of the questions that arose from the tundra lake study was whether the lakes can be completely recharged after significant water extraction. The answer to this question depends on several factors, some of which include pre-winter soil conditions, anticipated snowmelt recharge in spring, the drainage area that contributes to runoff to the lake, and expected rainfall and evaporation during the following summer. For example, an extremely dry summer and fall occurred in 2007. During that year, the Kuparuk River at Deadhorse had its lowest end-of-summer flow since 1971, when the U.S. Geological Survey initiated streamflow gauging at this site (Kane et al., 2008). The impact of the 2007 drought on the surface storage deficit was evident during the 2008 snowmelt runoff and annual water yield (Arp et al., 2012).

One of the ways to address the consequences of drought is to augment a lake's water supply with a snow fence. The proposed solution was a study of snowdrifts on the North Slope of Alaska to determine the volume of lake water recharge in response to melting snowdrifts. We selected two lakes with similar hydrological regimes 30 miles south of Prudhoe Bay near Franklin Bluffs: an experimental lake, where a snow fence was installed, and a control lake, where the natural regime was preserved. Weather and hydrologic data were collected from April 2009 to September 2011. A snowdrift was created with a snow fence $3 \mathrm{~m}$ tall and $130 \mathrm{~m}$ long, constructed in September 2009. High snow transport rates (up to $0.49 \mathrm{~kg} / \mathrm{s} / \mathrm{m}$ ) ensured that the snowdrift reached its equilibrium profile by winter's end. The snowdrift was $3 \mathrm{~m}$ deep as early as November 4, 2010. Total of six snow transport events built the drift during winter 2010-2011. The snowdrift completely melted in the beginning of July during both years of the experiment. Estimation of the total amount of snow captured by the snow fence was $21,378 \mathrm{~m}^{3}$ by April 24,2010 , and $16,152 \mathrm{~m}^{3}$ by April 16,2011 . In 
summer 2010, we had to lower the top of the snow fence by about $0.4 \mathrm{~m}$ as part of the maintenance effort; this lower snow fence resulted in less snow accumulated during next winter 2010-2011.

The impact of the snowdrift melt on the lake water volumes was measured and documented during summer 2010 and summer 2011. It is a challenge to separate the effect of snowdrift melt on lake water volume from all other components that contribute to the hydrologic system of the lake, such as gain or loss of water due to natural snowmelt, rainfall, evaporation, overland flow, and change in subsurface storage. We took a different approach of evaluating the lake water volumes during years of experiment against the lake water levels prior to the experiment. This baseline data were collected from April to September 2009 before installation of the snow fence. The results of the weather data analysis, summarized in the paragraph below, show that weather conditions (snow water equivalent, rainfall, and evaporation) in the baseline year (2008-2009) were conducive to high natural lake water levels. In contrast, rainfall was below average during the two years of the experimental snow fence, thus highlighting the contribution of the snowdrift to the lake during the dry years.

The average end-of-winter snow water equivalent (SWE) at Franklin Bluffs from 2000 to 2011 was $120 \mathrm{~mm}$. The measured SWE on the ground at the end of winter was $117 \mathrm{~mm}$ on April 25, 2010, and $121 \mathrm{~mm}$ on April 16, 2011. The baseline year had above-average SWE of $160 \mathrm{~mm}$ on April 29, 2009. Natural snow on the ground (as opposed to the snowdrift) completely disappeared by May 26 in 2009, June 4 in 2010, and May 30 in 2011. The snowdrift melted by July 7 in 2010 and July 4 in 2011, creating an additional 32 and 35 days of snowmelt supply augmenting the lake. In addition to this snowdrift meltwater, the lakes in the area received $36 \mathrm{~mm}$ of rainfall in summer 2010 and $31 \mathrm{~mm}$ of rainfall in summer 2011. These amounts represent the cumulative rainfall between June 6 and August 31. In summer 2009 (before the experiment), the lakes in the study area received significantly more rainfall $(85 \mathrm{~mm})$. Six years of rainfall records at this site (2006-2011) show that cumulative June-August rainfall can be as low as $9 \mathrm{~mm}$ (2007) and as high as $93 \mathrm{~mm}$ (2006). Thus, the local lakes received below-average rainfall during the experimental summer periods of 2010 and 2011 and above-average rainfall during the baseline summer (2009). Lake evaporation is the major natural water sink that causes a decrease in lake water levels during the open-water season. Evaporation pan measurements indicated that the potential evaporation in June, July, and August averaged $2.9 \mathrm{~mm} /$ day, $3.3 \mathrm{~mm} /$ day, and $2.4 \mathrm{~mm} /$ day in 2009, 2010, and 2011, respectively. Average daily lake evaporation rates in July and August were $2.6 \mathrm{~mm} /$ day in 2009, $2.6 \mathrm{~mm} /$ day in 2010, and $2.7 \mathrm{~mm} /$ day in 2011. Changes in subsurface storage were not directly taken into account. Large volumes of water were pumped from the experimental lake during summers 2009 and 2010 for the maintenance of the Dalton Highway. For analysis, these volumes were added to the measured lake volumes to obtain reconstructed data.

Water volumes in the lake were significantly elevated during both summers (2010 and 2011) of the snowdrift experiment. Comparison of lake water volumes during the experiment with the baseline year shows an increase in lake volume due to snowdrift melt of at least $21-29 \%$ at the end of summer. We estimated water cost at 1.9 cents per gallon during the first year and 0.8 cents per gallon during the second year. This estimate strongly depends on the cost of snow fence construction in remote arctic locations, which we assumed to be $\$ 7.66$ per square foot of frontal area. Project results were presented and discussed during multiple conferences and published in several journals (see list of references for details). Immediate use of the excess water provided by the snow fence occurred in summer 2010, when the Alaska Department of Transportation and Public Facilities used the water to maintain the Dalton Highway.

This research project was synergetic with the NETL project, "North Slope Decision Support System (NSDSS) for Water Resources Planning and Management." The volume of snow and water trapped by the snow fence was implemented in the NSDSS model and added to the annual water budget. This information allows one to account for snowdrift contributions during ice road planning with the NSDSS and assists with mitigating those risks associated with potentially unfavorable climate and hydrological conditions (that is, surface storage deficit and/or low precipitation). 


\section{CONTENTS}

Disclaimer

Acknowledgments

Abstract

Executive Summary

Report Details

Location of the experimental site

Land use permits

Hydrological and meteorological data collection

Snow fence design and location

Results and discussion

Snow transport and drift growth

Snowdrift melt

Precipitation and evaporation

Hydrological response of the lake

Water cost

North Slope Decision Support System

Conclusions

Graphical Material List

References 


\section{Report Details}

The science of controlling snow has a long history. Brown (1983) found the first known reference to snow fences in a Norwegian publication dated 1852 . At that time, farmers used snow fences to supply water for animals and plants. A newspaper in Alaska described the use of snow fences by Seward miners in the early twentieth century (Seward Weekly Gateway, 1909). In the 1970s and 1980s, considerable progress was made in increasing local water supplies by using snow fences (Jairell and Schmidt, 1990; Tabler and Sturges, 1986; Slaughter, 1974). In 1973, the U.S. Army Cold Regions Research and Engineering Laboratory experimented with the technique of using snow fences in Barrow, Alaska (Slaughter et al, 1975). McFadden and Collins (1978) used snow fences to supplement the water supply at Point Hope, a coastal Alaska village noted for its constant high winds. Tabler and his associates used the technique to enhance snow depth to increase water yield in a research watershed in Wyoming from 1983-1989 (e.g., Tabler and Sturges, 1986;

Tabler, 1994).

The underlying soil and rock material was found to be a key factor in success or failure of snow management for water resources (Sturges, 1989; Sturges, 1992). Tabler and Sturges (1986) showed that snow fence $396 \mathrm{~m}$ long and $3.8 \mathrm{~m}$ tall doubled snow deposition in the channel above a stream gauge, but meltwater failed to reach the gauge site. The soil was extremely permeable and underlain by deeply fractured granite, so water percolated into the ground. Conversely, study results in an area of continuous permafrost (e.g., Barrow, Alaska's Arctic Slope) were so successful that the resulting snowdrift lasted into July of the following summer, and runoff from the large snowdrift went directly to the village water supply reservoir (Slaughter, 1974; Slaughter et al, 1975; Hinkel and Hurd 2006). In this report, we follow up on previous work and present new data on snow transport and snowdrift growth and its hydrological effect on recharge of tundra lakes.

This report has three major sections: (1) experimental methods, (2) results and discussion, and (3) conclusions. The section on experimental methods includes a detailed description of the geographical location, permitting, field experiments, data collection, and snow fence design. The section on results and discussion summarizes the collected data and includes a discussion of Alaska's environmental issues. The conclusions section contains a summary of the research results. 


\section{Experimental methods}

\section{Location of the experimental site}

The Arctic Coastal Plain on the North Slope of Alaska is covered by numerous shallow lakes, ranging in size from a few tens of meters in diameter to more than $10 \mathrm{~km}$ long. In selecting a research site, we focused on lakes accessible from the Dalton Highway. Beyond the highway's terminus at Deadhorse are private roads owned by oil companies, with use restricted to authorized vehicles only. The selected research site, located near Franklin Bluffs, is accessible by a gravel road built by the Alyeska Pipeline Service Company (Figure 1A). We selected two lakes for use in this experiment (Figure 1B); one lake as an experimental lake, where the snow fence was constructed to evaluate the effect of snow drift on rising lake water levels (Figure $1 \mathrm{C}$ ), and the second lake as a control lake, where the natural regime was preserved.
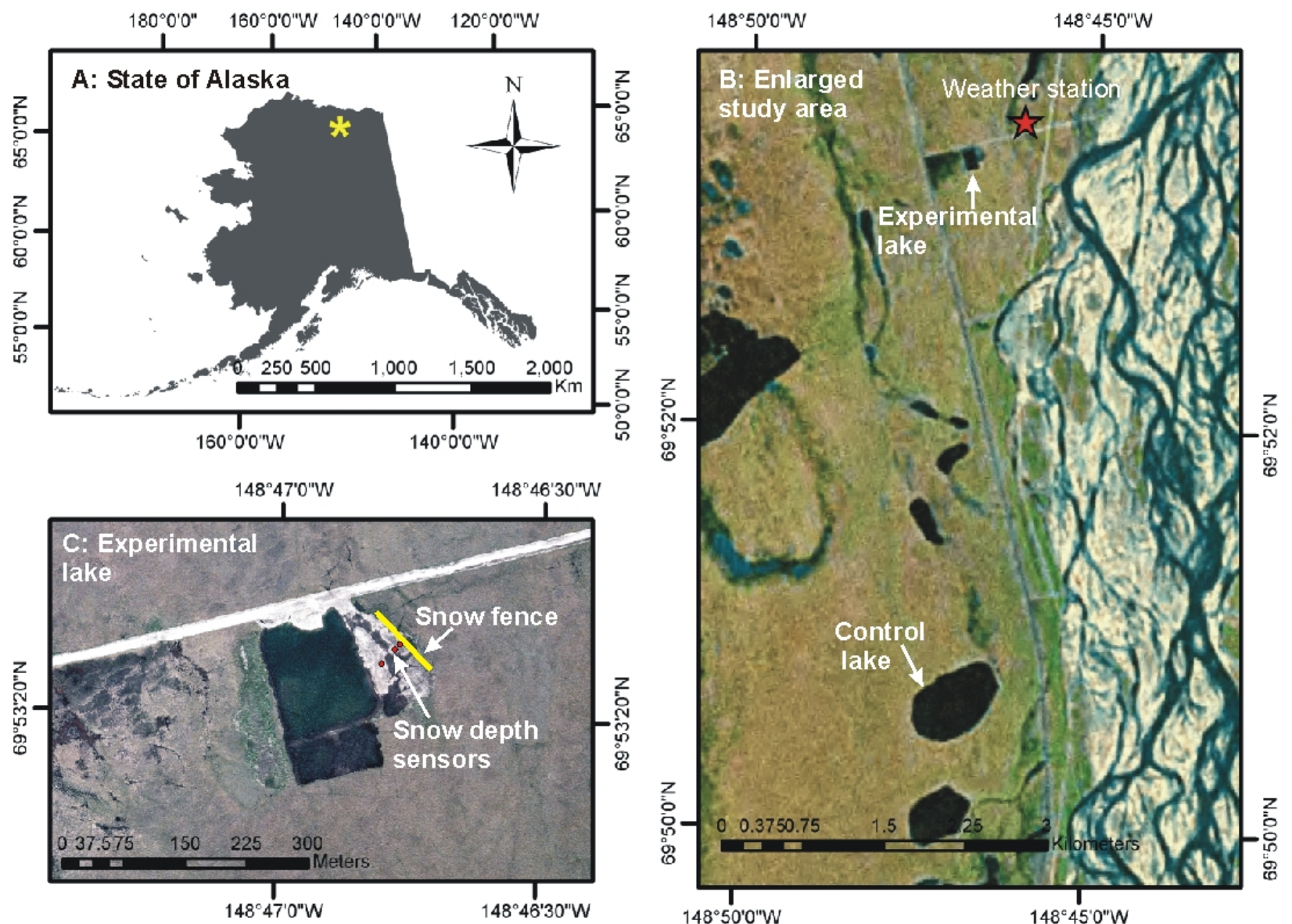

Figure 1. Map A shows the location of the study area in Alaska. Map B shows the location of the weather station and the experimental and control lakes. Map $C$ indicates the location of the snow fence and sonic sensors in the experimental lake watershed. 


\section{Land use permits}

The project fieldwork required land use permits from the Alaska Department of Natural Resources (DNR) and from the North Slope Borough (NSB). Land use permits \#LAS 27219 and NSB 09-410 were obtained from both agencies. These permits authorized installation of a snow fence and equipment to collect snow and hydrological data.

Letters of non-objection were obtained from two other agencies. One letter was needed from the Alyeska Pipeline Service Company to use their gravel access road. Another letter was required from the Alaska Department of Transportation and Public Facilities (ADOT\&PF), stating that our research did not interfere with its activities.

Completion reports, prepared in accordance with the special requirements listed in the permits and non-objection letters, were submitted to each agency upon the completion of this project. All sensors, towers, and snow fence were removed from the site in September 2011.
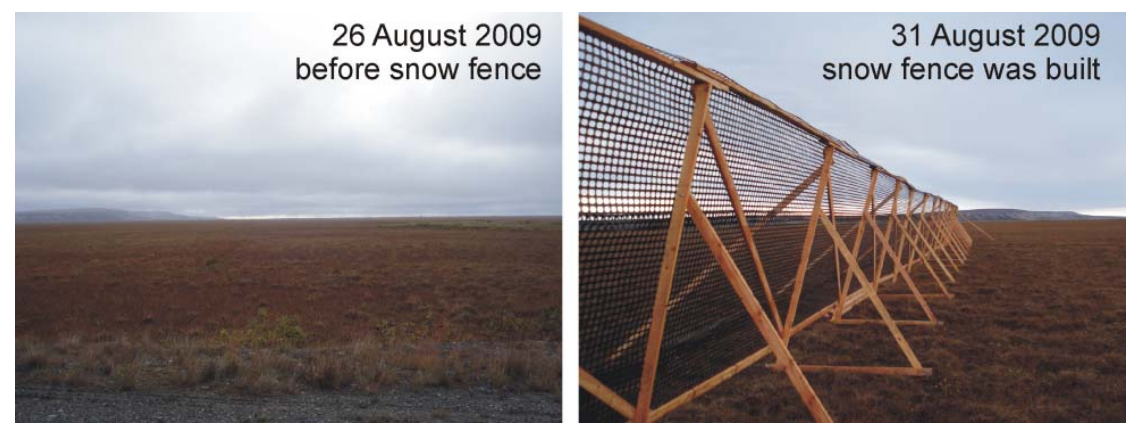

Figure 2. Example figure from the completion report showing site conditions before and after the snow fence construction.

\section{PERMITTING AGENCIES}

\section{$\triangle$ ALASKA DEPARTMENT OF NATURAL} RESOURCES

The Department of Natural Resources (DNR), Northern Oil and Gas, Division of Mining, Land \& Water office is responsible for managing state land and resources in the selected research area.

\section{NORTH SLOPE BOROUGH}

Project fieldwork required land use permits from the North Slope Borough (NSB), Department of Planning and Community Services.

\section{$\triangle$ ALYESKA PIPELINE SERVICE COMPANY AND ALASKA DEPARTMENT OF TRANSPORTATION AND PUBLIC FACILITIES}

The letters of non-objection, stating that our research does not interfere with the ADOT\&PF and with Alyeska Pipeline activities, were received from both agencies.

\section{Hydrological and meteorological data collection}

Data collection was an essential part of this project. The NOAA, National Weather Service, as well as other agencies collecting hydrometeorological data, have limited network coverage over this region. Severe climate conditions, an abundance of wildlife, and simply lack of access prevent regular data collection by most of the agencies. The stations that exist require high-cost maintenance to provide quality data collection; yet they provide invaluable information for engineers, scientists, and local communities. It is common practice on research projects in this area to set up independent data collection and/or collaborate with other ongoing projects.

We used a weather station at the Franklin Bluffs site that had been established and maintained under a National Science Foundation research project in 1990s. This weather tower (10 m tall) was located $500 \mathrm{~m}$ northeast of the experimental lake and was equipped with wind sensors, an air temperature, relative humidity, and rainfall gauge, an evaporation pan, and a sonic depth sensor. Another weather station was set up next to the experimental lake at the snow fence. A snow fence $3 \mathrm{~m}$ tall and $130 \mathrm{~m}$ long was equipped with three sonic sensors to monitor drift evolution. A camera and air temperature and relative humidity sensors were installed also. Both the $10 \mathrm{~m}$ tall weather tower and the snow fence weather site transmitted data via telemetry in real time. In both lakes, water levels were measured with vented pressure transducers. In addition, a bathymetry survey was conducted with an Acoustic Doppler Current Profiler (ADCP) and a DGPS to establish the water level/surface area/volume relationship. In summary, automated data 
collection was performed at three places: (1) the Franklin Bluffs weather station, (2) the Franklin Bluffs hydrological site at the gravel pit lake (referred to as the experimental lake), and (3) the Franklin Bluffs hydrological site at the control lake. In quarterly reports, we presented detailed lists of the instrumentation, sensor location, and data collection period.

\section{LAKES AND STREAMS $\quad$ WEATHER STATION SNOW FENCE}

WATER LEVEL, BATHYMETRY, DISCHARGE, SNOW DEPTH, AND SNOW WATER EQUIVALENT

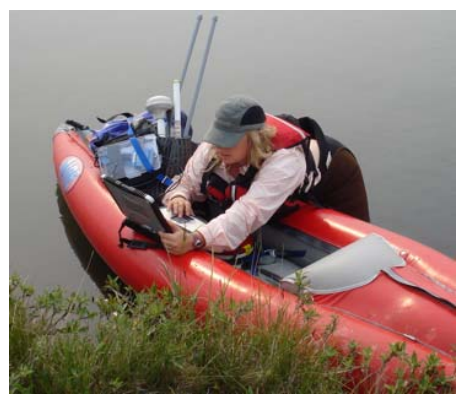

WIND SPEED AND DIRECTION, AIR TEMPERATURE, RELATIVE HUMIDITY, RAINFALL, POTENTIAL EVAPORATION, AND AUTOMATED SNOW DEPTH

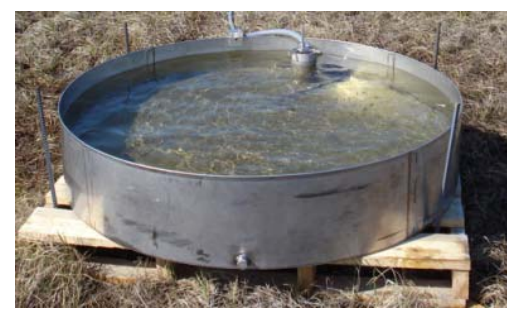

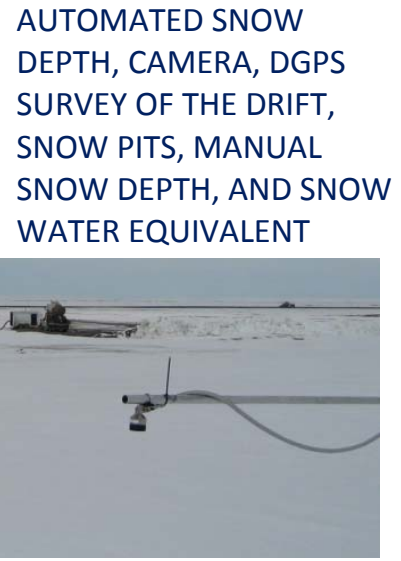

In addition to automated data collection, other data were collected manually. Such data included bathymetry surveys to estimate the lake volume, snow surface elevation surveys to define the volume of the drift, extensive snow depth measurements to learn about the natural snow conditions, snow water equivalent measurements to estimate the water content of the snowpack, and streamflow discharge measurements. This data collection required regular visits to the Franklin Bluffs sites. Field trip preparation, field data collection, and associated data post-processing including observational data quality assessment and quality control (QA/QC) were large components of the project.

\section{Snow fence design and location}

On the North Slope of Alaska, most snow is moved by wind because winds there are ample and blow easily over the low-growing vegetation. Any barrier that reduces wind speed causes transported snow to be deposited on the barrier's lee side. Snow fences are widely used to control the amount of snow that accumulates or erodes. Although snow fences can augment water supplies by altering the distribution of snow, they also make "new" water available by reducing sublimation loss from blowing particles. Tabler and Sturges (1986) provided an example of a case in Wyoming where more than half of the blowing snow sublimated over transport distances of $3000 \mathrm{~m}$ (about $2 \mathrm{mi}$ ). Liston and Sturm (2004) reported that blowing snow sublimation on the North Slope of Alaska can be as high as $50 \%$ of the total winter precipitation or $35 \%$ of the annual precipitation. Because sublimation of blowing snow is a difficult measurement, more studies are needed to verify previous measurements. Despite the lack of exact estimates, there is agreement that controlling snow transport with a snow fence decreases sublimation loss and increases net snow water equivalent (SWE) on the ground.

Guidelines for the design of snow fences to control blowing and drifting snow were developed by Ronald Tabler (e.g., Tabler, 1994). These guidelines, which are widely used in the United States as well as internationally, were used to design the snow fence for this project. We designed a snow fence large enough to create a snowdrift that would capture a volume of snow comparable to the volume of water in the lake in summer. We used empirical relationships between snow transport, winter precipitation, and fetch published in Tabler (1994) to verify that the desired size of the 
snowdrift was achievable in the study environment. A Wyoming-type snow fence $3 \mathrm{~m}$ tall and $130 \mathrm{~m}$ long was constructed in September 2009. In March 2010, the snowdrift reached its equilibrium profile at about $21,500 \mathrm{~m}^{3}$ of snow.

Two types of snow fences are commonly used to control snow transport on the North Slope of Alaska: a Wyoming fence and a pole-supported fence. Figure 3 shows examples of these two fence types. The main difference in the performance of these two designs is related to the foundation depth that is needed to secure the structure in frozen ground. One of the advantages in using the Wyoming-type snow fence is that its rotational moments are almost an order of magnitude less than the rotational moments of the pole-supported design.

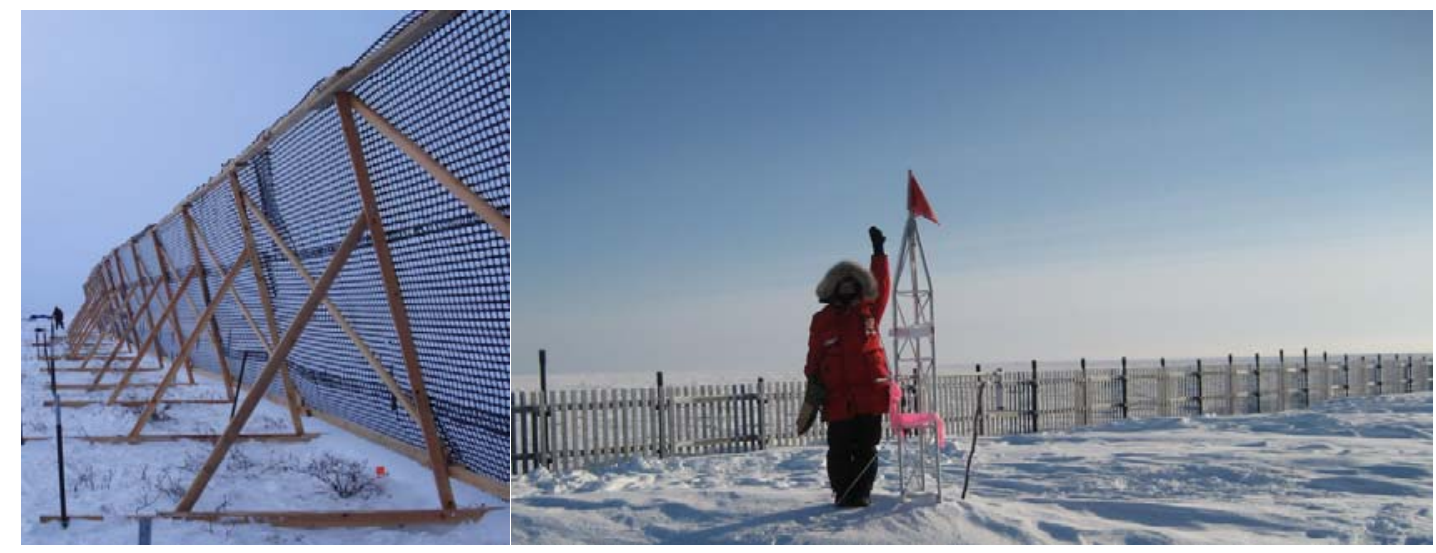

Figure 3. Photograph on the left shows Wyoming-type snow fence near Franklin Bluffs, North Slope of Alaska (September 2010). The photograph on the right shows a $4 \mathrm{~m}$ tall pole-supported snow fence in Barrow half hidden under the snowdrift (March 6, 2008). The researcher is standing on top of the snowdrift next to a $5 \mathrm{~m}$ tall instrumentation tower almost buried under the snow.

The structural part of the Wyoming-type snow fence was built of wood and covered with Resinet SF50 plastic mesh (Figure 3, left panel). The snow fence was anchored at both ends of the sill by fence posts drilled into the permafrost. The snow fence was placed next to the experimental lake, as shown on Figure 4.
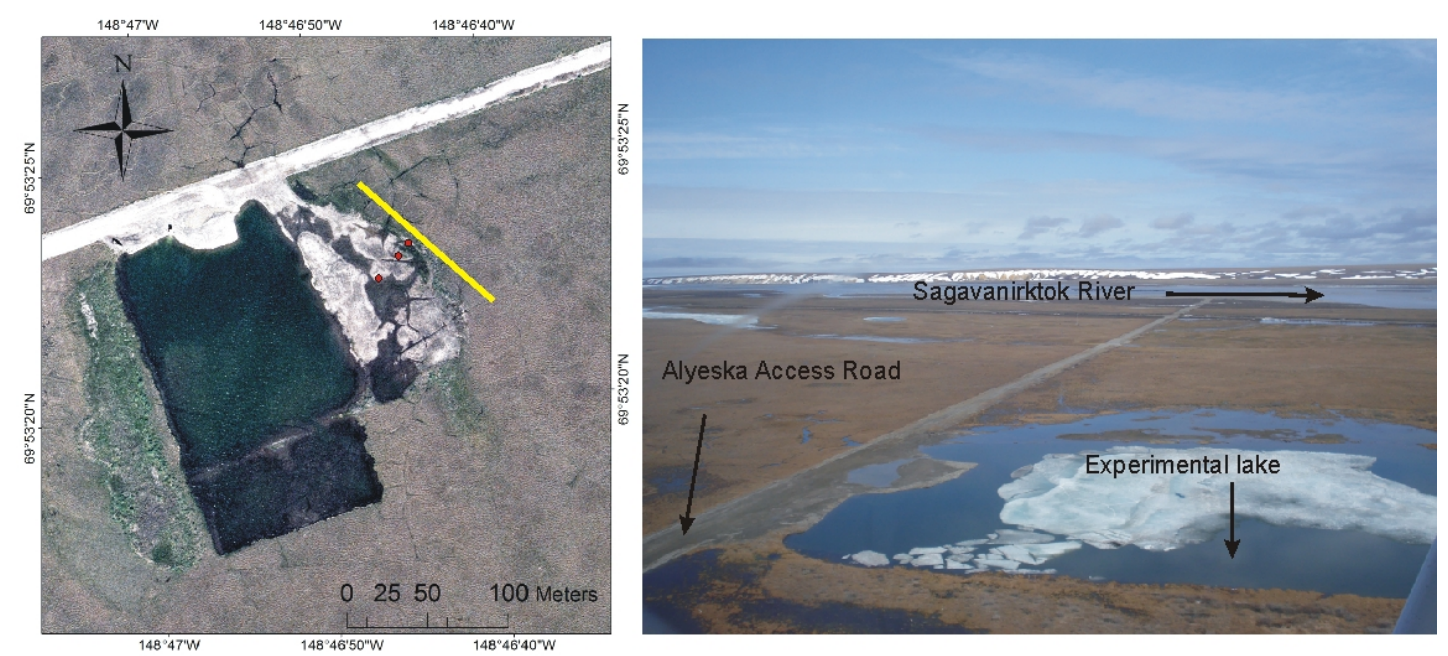

Figure 4. Actual snow fence location is shown as a yellow line on the left panel. Red dots show locations of the three snow depth sonic sensors (10 m, $16 \mathrm{~m}$, and $34 \mathrm{~m}$ away from the fence). Photograph on the right shows experimental lake on June 7, 2009. 
Snow fence placement was determined by several factors, One consideration was that the fence must be nearly perpendicular to the prevailing wind direction to collect the maximum transported snow. Another consideration was that most of the meltwater must flow into the lake. The snow evolution model system SnowModel (Liston and Elder, 2006) was applied to simulate snow erosion/deposition and analyze the optimum location for the snow fence (Figure 5). Processes simulated by SnowModel included accumulation from snow precipitation, blowing-snow redistribution and sublimation, snow-density evolution, and snowpack ripening and melt. SnowModel is an aggregation of five submodels: MicroMet distributes meteorological data; EnBal calculates surface energy exchanges; SnowPack simulates snow depth and water-equivalent evolution; SnowTran-3D accounts for snow redistribution by wind; and SnowAssim assimilates available observations as part of the SnowModel integrations. Model simulations were performed for two different snow fence positions around the lake (Figure 5). This sensitivity study provided the required background to determine the optimal snowdrift position. Model simulations were performed on grid increments of $10 \mathrm{~m}$ and temporal increments of 1 hour from September 1,2007, to June 15, 2008. Meteorological data from a $10 \mathrm{~m}$ tall weather station at Franklin Bluffs together with a digital elevation model and vegetation coverage were used to run SnowModel simulations. The study domain was $1.4 \mathrm{~km}$ in width by $1.8 \mathrm{~km}$ in length, covering the watershed of the experimental lake and the surrounding area that serves as a source of snow transport from the northeast (Figure 5A). The resultant snow water equivalent distributions are presented in Figure $5 \mathrm{~B}$ and Figure $5 \mathrm{C}$. The red color indicates the snowdrift location by the end of winter on May 10, 2008. Model simulations showed that snow fence Location $A$ captured slightly more snow than snow fence Location B.
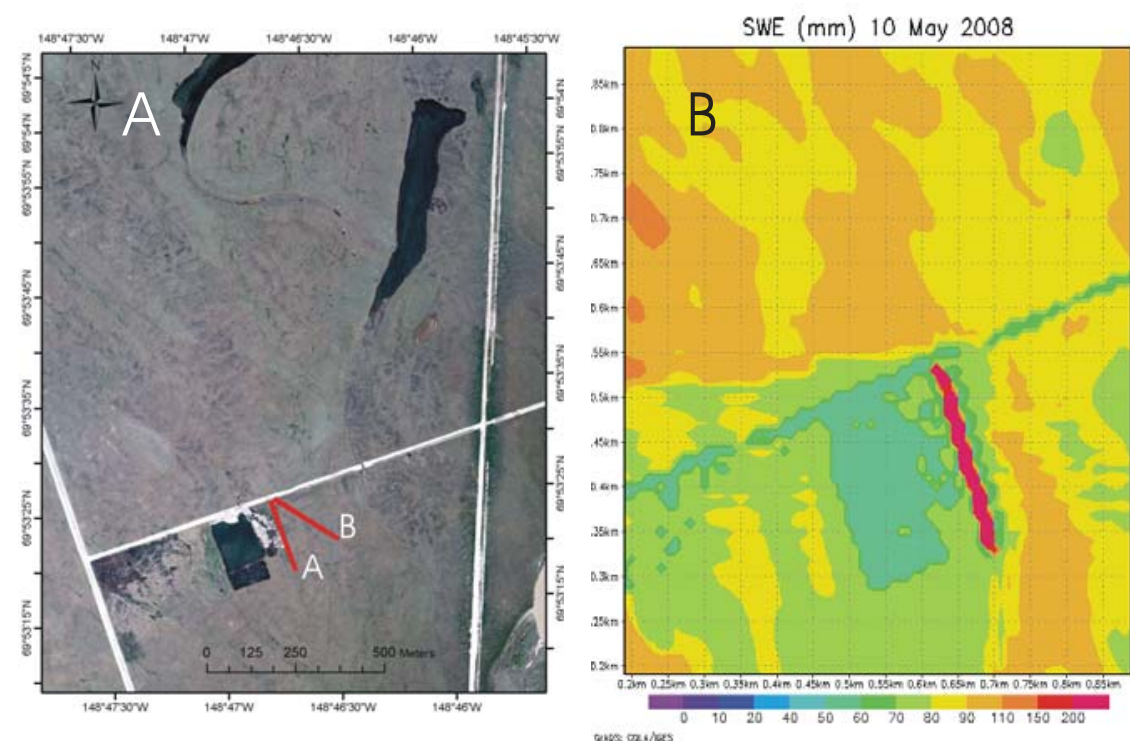

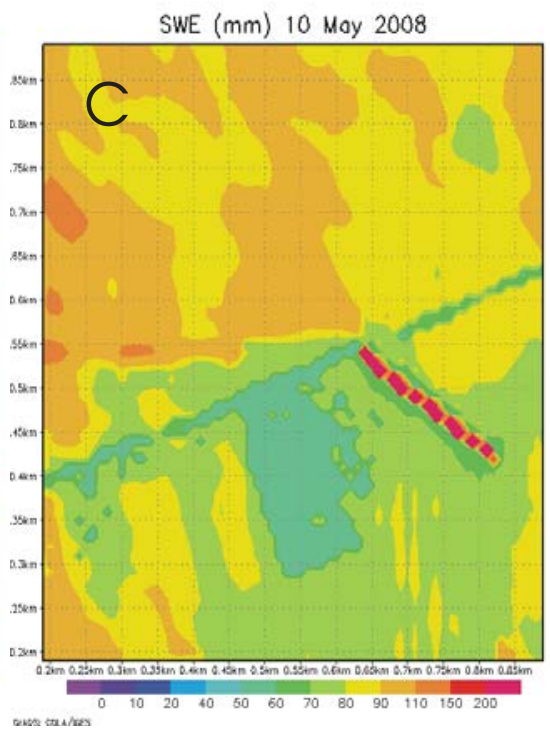

Figure 5. Left panel shows SnowModel simulation domain and proposed snow fence locations (line A and line B). Simulated snow water equivalent (SWE) for the proposed snow fence location $A$ is shown on the central panel. Simulated snow water equivalent (SWE) 2008 for the proposed snow fence location B is shown on the right panel.

Given the extremely low gradient on the Coastal Plain, a snow fence should be placed very close to the lake at a location where the surface slopes toward the lake. Building a snowdrift directly on the lake ice was not recommended, since the snowdrift creates additional load on the ice and increases the ice melt period of the lake. Based on these considerations, we selected the preferred snow fence, Location A, as shown in Figure 4.

In addition to the snow fence, we installed instrumented towers on the downwind side of the fence at 10,16, and $34 \mathrm{~m}$ to monitor snowdrift growth and melt (Figure 6). Each tower was equipped with a sonic depth sensor that measured the distance from the sensor to the surface. These three towers were connected to a fourth tower, which was placed 
next to the fence itself. This fourth "snow fence" tower was equipped with the data logger, power supply, solar panel, camera, antenna, radio, and relative humidity and air temperature sensors. The radio transmitted data and camera images from the snow fence site to the WERC server in real time. This instrumentation provided data that was used to measure snow transport episodes and to assess snowdrift growth and melt.
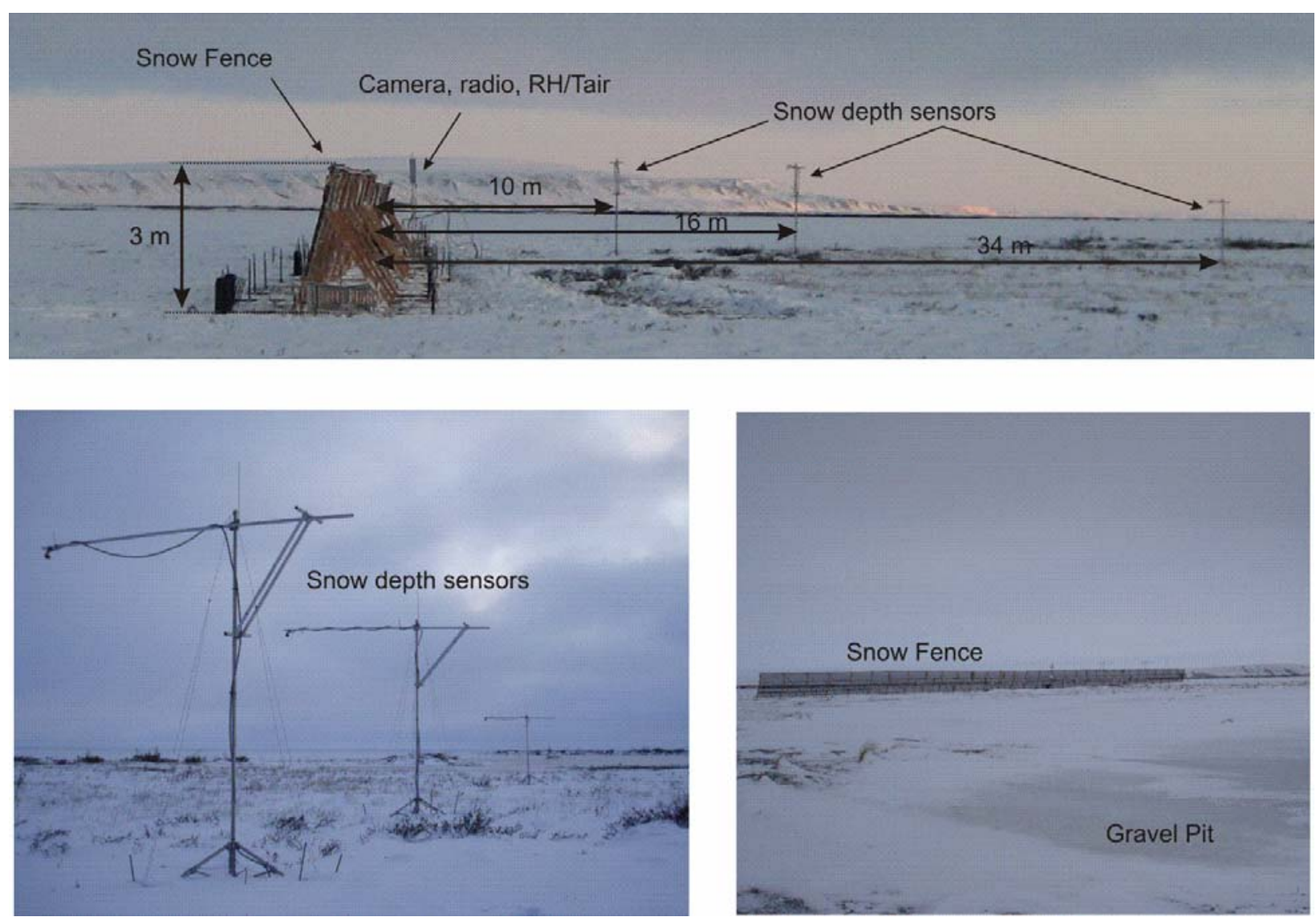

Figure 6. Top panel shows location of the snow depth sensors on the lee side of the snow fence. Bottom pictures show locations of the snow fence and instrumentation relative to the gravel pit. These photographs were taken shortly after snow fence installation on September 28, 2009. 


\section{Results and discussion}

Results of the project are divided into six sections: (1) snow transport and drift growth; (2) snowdrift melt; (3) precipitation and evaporation; (4) hydrological response of the lake; (5) water cost, and (6) the North Slope Decision Support System. We quantified the hydrologic effect of the snowdrift on the lake in terms of changes in lake water volumes and the timing of additional snowmelt recharge. We evaluated lake water volumes during the years of the experiment by comparing them with the lake water volume of the baseline year before the experiment. General weather conditions for all these years were analyzed and summarized in the lake water balance. Finally, cost considerations and project data were provided to the agencies.

\section{Snow transport and drift growth}

The accurate assessment of snow transport during wind events is a prerequisite to reliable estimation of snowdrift growth and snow loads on infrastructure. This section presents the results from two years of snow transport and snowdrift measurements designed to improve such assessments. We addressed three questions: How much snow is being transported? How often does snow transport occur? How long does snow transport last?

To measure the timing and magnitude of snow transport episodes, we used snow depth sensors installed along the drift cross-section (Figure 6), the principle being that snow depth measurements at three points correspond with the volume of the entire snowdrift. Figure 7 shows an example of the snow depth records of one winter season (October 2009-June 2010). Several times during the winter, sharp increases in depth occurred at one or more sonic sensors, indicating a snow deposition event (SDE). Large SDEs can be seen in October, December (near the end of December), and at the end of January (Figure 7). We define an SDE as a period of blowing snow that lasted more than two hours, was separated from other periods by at least two hours of calm, and resulted in more than $0.3 \mathrm{~m}$ of change in snow depth. However, if all sensors reported the same change in snow depth, we identified the event as a snowfall. Sonic sensors "topped off" and failed to register an event if a snowdrift reached its equilibrium profile and the fence was full. For example, in Figure 7 see the end of March and April 2010.

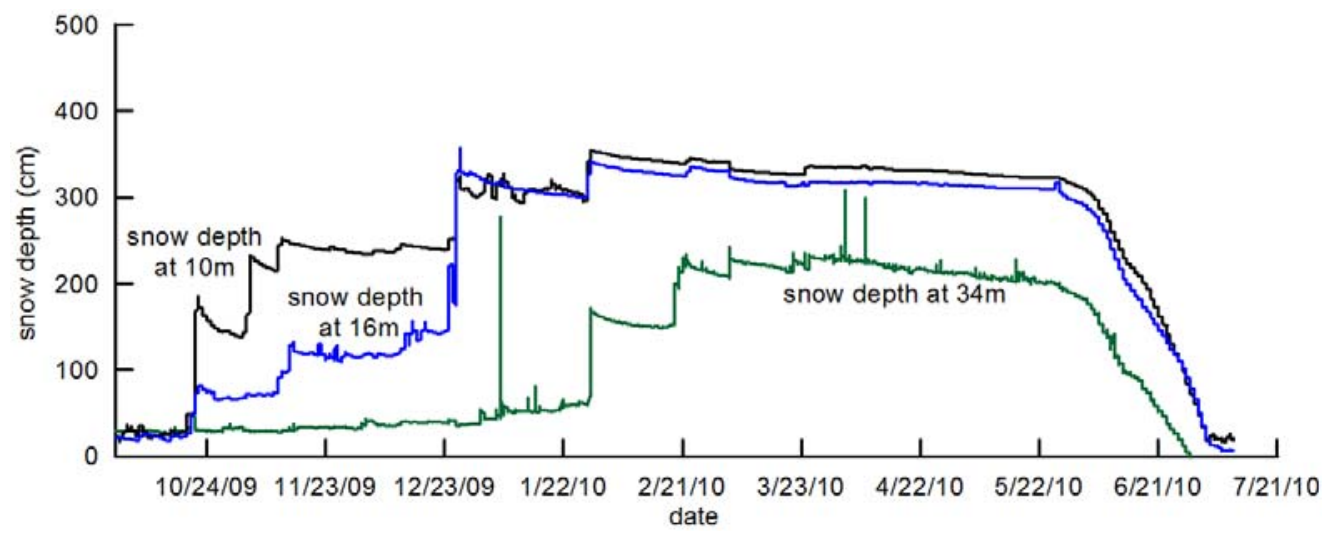

Figure 7. Snow depth measured by three sonic sensors, located at 10, 16, and $34 \mathrm{~m}$ perpendicular to the snow fence.

We selected the Franklin Bluffs area because of its strong winds. Winds in excess of $17 \mathrm{~m} / \mathrm{s}$ were five times more likely to occur at Franklin Bluffs than at the foothills of the Brooks Range (Imnavait Creek) and ten times more likely to occur than on the coast in Barrow (Sturm and Stuefer, 2013). These strong winds cause snow transport rates of up to 0.49 $\mathrm{kg} / \mathrm{s} / \mathrm{m}$ (Table 1). Six snow transport events built the drift during the winter of 2010-2011. Our data show that the drift was $3 \mathrm{~m}$ high as early as November 4, 2010. An example of snow transport event is shown in Figure 8. 


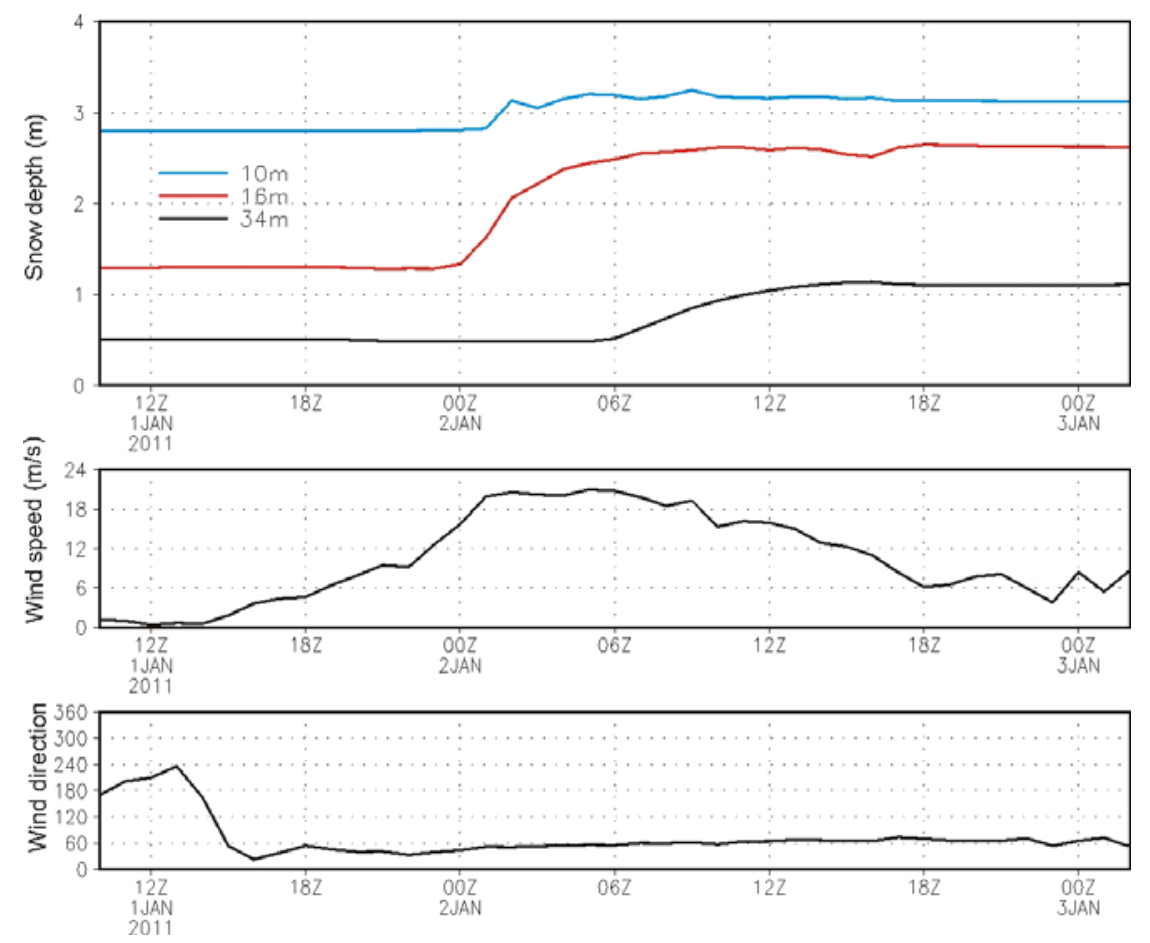

Figure 8. A typical example of a snow deposition event (SDE) at Franklin Bluffs, recorded by snow depth sensors. Within just several hours, a meter of snow had been deposited at the fence. The reported wind speed is an hourly averaged.

We combined the time-dependent snow depth measurements at the fence (Figure 7) with the snowdrift profile surveys to produce (1) a series of snow volumes before and after snow deposition events, and (2) daily drift volumes during the snowmelt. The drift profiles were either measured in the field with the DGPS snow surface survey or calculated from the snow depths recorded by sonic sensors. The estimation of the snowdrift area from the DGPS survey was $11,830 \mathrm{~m}^{2}$. The estimation of the lake surface area from the bathymetry survey was $21,000 \mathrm{~m}^{2}$. The snow fence accumulated $21,378 \mathrm{~m}^{3}$ of snow by April 24, 2010, which is equivalent to $75 \mathrm{~cm}$ SWE per snowdrift area or $42 \mathrm{~cm}$ SWE per lake area. Snow volume at the fence in April 2011 was 16,152 $\mathrm{m}^{3}$ (59 cm of SWE per snowdrift area or $33 \mathrm{~cm}$ of SWE per lake area) which is $24 \%$ less when compared with the snowdrift volume in April 2010 (Table 2). We had to lower the fence as part of the maintenance in summer 2010; as a result, less snow was collected.

Snow density was periodically measured with the snow cores and snow pits. We calculated the snow deposition rate $\left(Q_{d}\right)$ per meter of fence length by combining information from the sonic sounders, the drift profile surveys, and the snow cores (Stuefer and Sturm, 2012):

$$
Q_{d}=\frac{\rho * \Delta V}{\Delta t} * \eta
$$

where $\rho$ is snow density $\left(\mathrm{kg} / \mathrm{m}^{3}\right), \Delta V$ is the change in drift volume during an SDE $\left(\mathrm{m}^{3} / \mathrm{m}\right.$ or cubic meter per linear meter of the snow fence length), $\Delta t$ is the duration of the snow transport ( $s$ ), and $\eta$ is snow fence trapping efficiency (dimensionless). Because $\eta$ has not been well established and most of the SDEs occurred during the earlier stages of drift development when trapping efficiency tends to be high, $\eta$ is assumed to be 1 for purposes of calculation (Tabler, 1980). The results of the snow deposition rates are given in Table 1. Most of the snow deposition events occurred between November and February. At this particular location, they lasted from a few hours to one day. In other areas of the North Slope, the duration of snowdrifting events can be much longer, up to several weeks, as was observed in Barrow (Sturm and Stuefer, 2013). 
Table 1. Snow deposition events and hourly-averaged weather data at $10 \mathrm{~m}$ height.

\begin{tabular}{|c|c|c|c|c|}
\hline Date & $Q_{d}(\mathrm{~kg} / \mathrm{s} / \mathrm{m})$ & Wind speed* $(\mathrm{m} / \mathrm{s})$ & Air temperature $\left({ }^{\circ} \mathrm{C}\right)$ & Relative humidity (\%) \\
\hline $10 / 21 / 2009$ & 0.49 & 18 & -8.3 & 95.2 \\
\hline $11 / 4 / 2009$ & 0.16 & 15.2 & -18.4 & 88.3 \\
\hline $11 / 11 / 2009$ & 0.20 & 15.9 & -18.4 & 88.6 \\
\hline $11 / 14 / 2009$ & 0.03 & no data & no data & no data \\
\hline $12 / 26 / 2009$ & 0.37 & 20 & -23.5 & 83.4 \\
\hline $1 / 28 / 2010$ & 0.20 & 20.8 & -24 & 82.7 \\
\hline $2 / 19 / 2010$ & 0.06 & 20 & -16.1 & 89.4 \\
\hline $11 / 3 / 2010$ & 0.32 & 20.4 & -9.1 & 95.5 \\
\hline $1 / 1 / 2011$ & 0.32 & 21 & -25.3 & 81.7 \\
\hline
\end{tabular}

*Wind speed is reported as maximum hourly-averaged wind speed during the snow transport episode; air temperature and relative humidity were averaged during the duration of snow transport.

To put these observations in perspective, all previous measurements of snow transport have been reviewed (Sturm and Stuefer, 2013). This review showed that snow transport observations from Franklin Bluffs fall on the high end of data from the polar regions, meaning that the surrounding area provides an abundance of wind-blown snow during winter. Quantification of wind-blown flux in Table 1 can be used to provide background information for the engineering design of snow fences, roadways, and other structures.

\section{Snowdrift melt}

To calculate the snowdrift volume during melt and the corresponding meltwater output, we developed a model based on input measurements from three SR50 snow depth sensors located on leeward side of the fence. We approximated the snowdrift shape with four simple geometric shapes, as shown by the schematic diagram in Figure 9.

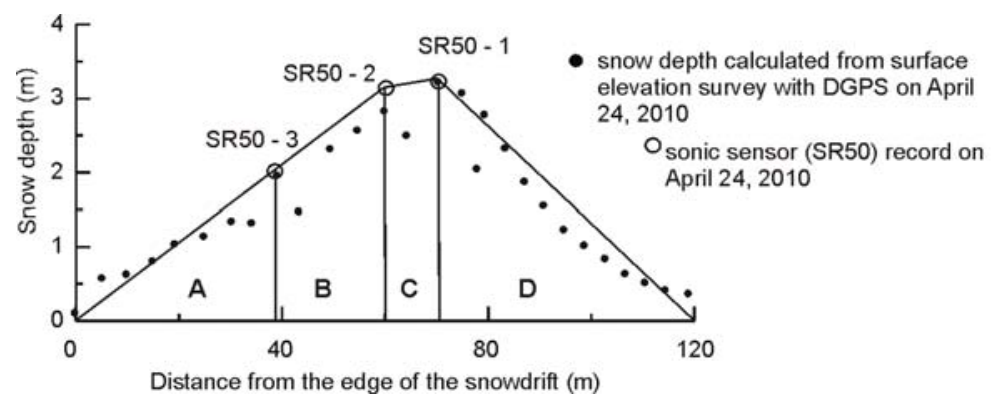

Figure 9. Schematic diagram showing an approach to calculating daily snowdrift melt based on records from the three SR50 sensors. 
The sum of four areas gave the volume of the snowdrift per meter fence. The main assumption for this model was that snowdrift shape satisfies geometric similitude as it melts. We applied a geometric scale factor based on SR50 records to calculate the snowdrift volume change in time. The modeled drift volume from an SR50 sensor approximates the measured snowdrift volume very well. The difference between the modeled and measured snowdrift volume ranged from 1 to $6 \%$ (Table 2).

Table 2. Comparison of snowdrift volume calculated from the snow surface elevation survey with DGPS (observed) and from the sonic snow depth sensor SR50 records (modeled).

\begin{tabular}{|ccccccccc}
\hline & \multicolumn{2}{c}{ April 16, 2011} & \multicolumn{2}{c}{ June 5, 2011} & \multicolumn{2}{c}{ April 24, 2010 } & May 30, 2010 \\
\cline { 2 - 8 } & Observed & Modeled & Observed & Modeled & Observed & Modeled & Observed & Modeled \\
\hline Snow volume, $\mathrm{m}^{3}$ & 16152 & 15893 & 10467 & 9820 & 21378 & 20650 & 19315 & 19118 \\
\hline Snow density, $\mathrm{kg} / \mathrm{m}^{3}$ & & 435 & 519 & 414 & 481 \\
\hline Water volume, $\mathrm{m}^{3}$ & 7026 & 6913 & 5432 & 5097 & 8850 & 8531 & 9291 & 9196 \\
\hline
\end{tabular}

These modeled snowdrift volumes were converted to SWE using snow density. Resultant curves, often called depletion curves, are shown in Figure 10. Snowdrift depletion curves were compared against depletion curves that are not affected by snowdrift. This comparison shows that natural snowpack disappeared on June 4 in 2010 and on May 30 in 2011. The snowdrift created an additional snowmelt supply to the lake until the beginning of July.

The snowdrift created an additional 34 days of snowmelt supply in 2011 and an additional 32 days in 2010. Given the short summers in the Arctic, with the warmest months in June and July, this additional water supply offset drying of the lake for at least the month of June (Stuefer, 2011).

Snow drift depletion curves in 2010 (left) and 2011 (right)
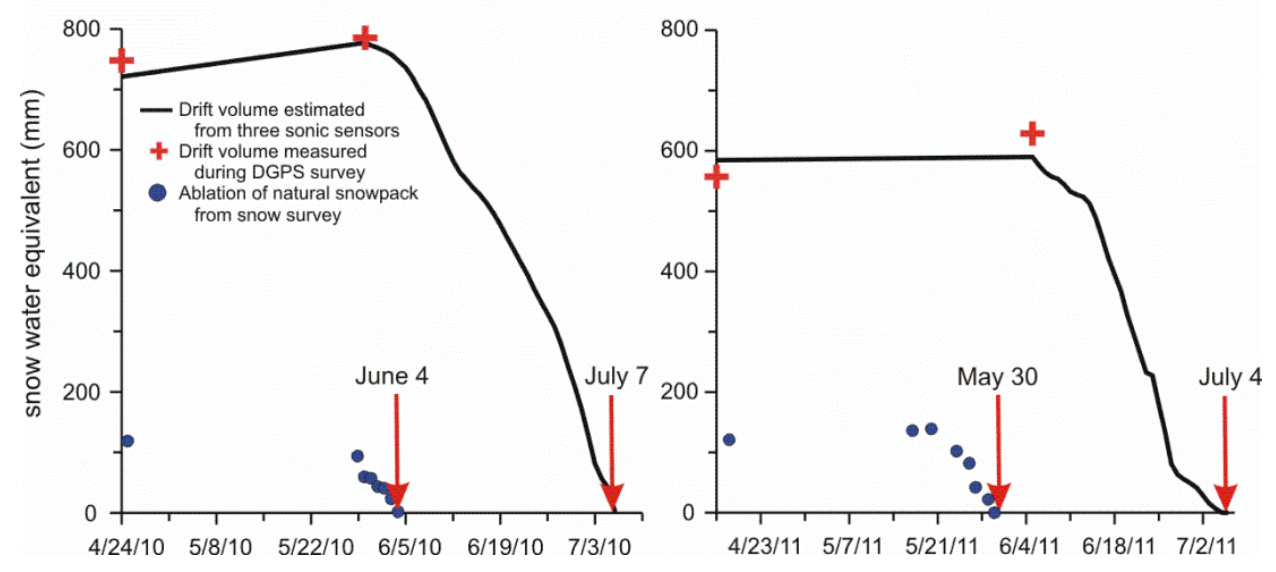

Figure 10. Depletion curve of snowdrift and natural snowpack in 2010 and in 2011. 


\section{Precipitation and evaporation}

The purpose of this section is to compare weather conditions in 2009, 2010, and 2011 with each other and with the historical record, when available. The weather conditions that directly affect the amount of water in a lake are snow water equivalent on the ground at the end of winter, summer rainfall, and evaporation. Most water is supplied to the lake hydrologic system during snowmelt (Bowling et al., 2003). After snowmelt, water volumes in the lakes decrease throughout the summer, when water loss due to evaporation is considerably greater than water gain due to rainfall. This balance switches in August, when air temperature drops, evaporation decreases, and rain (or snow) is more likely to occur. August is generally the wettest month of the year. Some of the summer surface storage deficit in the active layer and in surface water bodies (lakes, ponds, wetlands) is recharged during this time.

\section{END-OF-WINTER SNOW WATER EQUIVALENT}

End-of-winter snow water equivalent (SWE) serves as a metric for winter precipitation (less sublimation). The average SWE from 2000 to 2011 for this location was $120 \mathrm{~mm}$. End-of-winter SWE has been as low as $66 \mathrm{~mm}$ in 2007 and as high as $195 \mathrm{~mm}$ in 2003. Data from 2000 to 2008 were collected by WERC/UAF researchers under different projects funded by several sources. Data from 2009, 2010, and 2011 were collected under the umbrella of this project. The baseline year (before the experiment) had above-average SWE of $160 \mathrm{~mm}$ on April 29, 2009. Snow water equivalent during the years of this experiment was measured at $117 \mathrm{~mm}$ on April 25, 2010, and at $121 \mathrm{~mm}$ on April 16, 2011. In comparison with previous years, natural snow depth and SWE were close to average during the years of this experiment (2010 and 2011) (Figure 11), while the amount of snow during the baseline year (2009) was significantly above average.

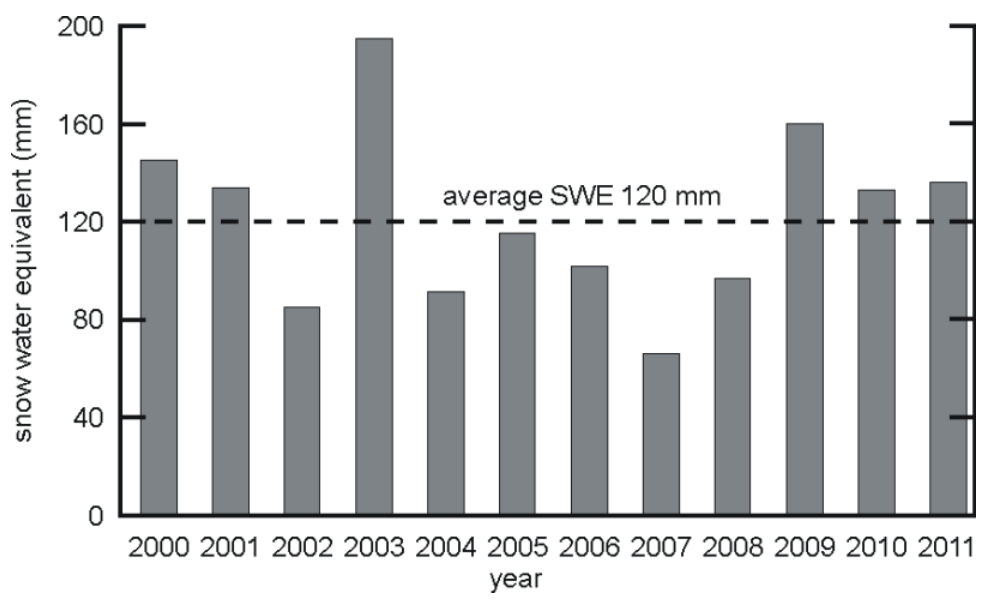

Figure 11. Long-term observation of end-of-winter snow water equivalent at Franklin Bluffs, 2000-2011.

\section{SUMMER RAINFALL}

Six years of rainfall records at the Franklin Bluffs site showed that cumulative June-August rainfall has been as low as 9 $\mathrm{mm}$ in 2007 and as high as $94 \mathrm{~mm}$ in 2006 (Figure 12). During the years of the snow fence experiment, the lake received $36 \mathrm{~mm}$ of rainfall in summer 2010 and $31 \mathrm{~mm}$ of rainfall in summer 2011. In summer 2009 (before the experiment), the lake received $85 \mathrm{~mm}$ of rainfall. This amount represents cumulative rainfall between June 6 and August 31. Summer 2011 was relatively dry on the entire Coastal Plain. Thus, the lake received below-average rainfall during the experiment in summers 2010 and 2011, and above-average rainfall for the baseline summer (2009). 
Cumulative summer rainfall at Franklin Bluffs weather station.

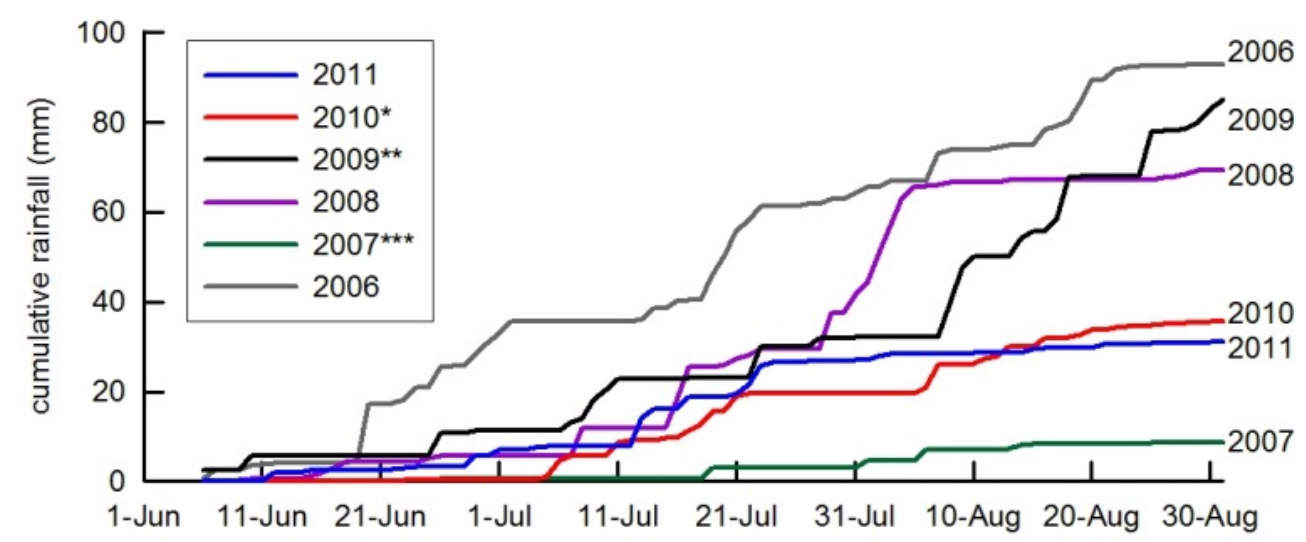

* North White Hills (DFM3) rainfall was used to estimate Franklin Bluffs rainfall in summer 2010 (see quarterly report 4, 2010).

** North White Hills (DFM3) rainfall was used to estimate Franklin Bluffs rainfall from July $8-29,2009$.

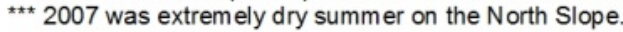

Figure 12. Cumulative summer rainfall from June 6 to August 31 at Franklin Bluffs. Bias-correction was applied to daily rainfall data.

Combining winter and summer precipitation, one can estimate the range of the annual precipitation from $75 \mathrm{~mm}$ in 2007 to $245 \mathrm{~mm}$ in 2009. Regional differences in Alaska are strongly reflected in precipitation distribution from south to north. Climate records show that the highest observed annual precipitation total is 5,728 $\mathrm{mm}$ on Baranof Island in Southeast Alaska. In contrast, the Prudhoe Bay area on the Beaufort Sea coast has the lowest average precipitation at $92 \mathrm{~mm}$ per year (Shulski and Wendler, 2007). From an environmental standpoint, the Coastal Plain is classified as a desert, that is, an area that receives less than $250 \mathrm{~mm}$ of precipitation each year. For both years of this experiment, rainfall was below average for this region, whereas the baseline year had above-average rainfall.

\section{EVAPORATION}

\section{Potential evaporation}

In order to develop general methods for estimating evaporation from lakes, hydrometeorologists have formulated the theoretical concept of potential evaporation (also called free-water evaporation), defined as evaporation that would occur from an open-water surface in the absence of advection and change in heat storage (Dingman, 2008). A direct approach in determining potential evaporation is to expose a cylindrical pan of liquid water to the atmosphere and to solve the following simplified water balance equation for a chosen time period:

$$
E=P-\left(V_{2}-V_{1}\right),
$$

where $V_{1}$ and $V_{2}$ are the storage volumes at the beginning and end of the chosen period, and $P$ is precipitation during that time. We installed a standard "Class-A" evaporation pan (used by the U.S. National Weather Service) to measure potential evaporation. The picture shown with Table 3 is of the evaporation pan at the Franklin Bluffs field site, about $500 \mathrm{~m}$ from the experimental lake. Evaporation pan measurements indicated that potential evaporation in June, July, and August averaged $2.9 \mathrm{~mm} /$ day, $3.3 \mathrm{~mm} /$ day, and $2.4 \mathrm{~mm} /$ day in 2009, 2010, and 2011, respectively (Table 3). 
Table 3. Potential evaporation at Franklin Bluffs, North Slope of Alaska.

\begin{tabular}{|c|c|c|}
\hline DATES & POTENTIAL EVAPORATION $(\mathrm{mm})$ & \\
\hline $6 / 9 / 2009-8 / 31 / 2009$ & 242 & 267 \\
$6 / 4 / 2010-8 / 23 / 2010$ & 225 & \\
$6 / 3 / 2011-9 / 6 / 2011$ & 25 & \\
\hline
\end{tabular}

\section{Evaporation from the lake}

In terms of practical considerations, an evaporation pan differs from a lake in having far less heat-storage capacity, in lacking surface or groundwater inputs or outputs, and, with a raised pan like the Class A one, in having the sides exposed to the air and sun and the bottom exposed to air circulation. These differences significantly affect energy balance, elevating the warm season average water temperature and vapor pressure of the water surface of the pan relative to that of a nearby lake.

Lake evaporation is often determined by adjusting potential evaporation to account for advection and heat-storage effects in a given lake. Across the United States, the ratio of lake evaporation to pan evaporation, called the pan coefficient, is about 0.7 on average (Dingman, 2008). Kohler et al. (1955) pointed out that this value should be applied only to annual data and only if effects of wind (advected) energy into the lake and heat transfer through the pan are considered (Winter, 1981). In addition, the presence of floating or grounded ice in June changes the surface albedo, water temperature, and open-water surface area, affecting lake evaporation and the pan coefficient. Even with these considerations, evaporation pans can still provide a representative estimate of lake evaporation during the ice-free period when an appropriate pan coefficient is known. Two studies have calculated pan evaporation coefficients for lakes located in the vicinity of Franklin Bluffs (Kane and Carlson, 1973; Mendez, 1997). Kane and Carlson (1973) reported cumulative pan evaporation for July and August and calculated lake evaporation of $136 \mathrm{~mm}$ in July and 102 $\mathrm{mm}$ in August. The pan coefficient was estimated to be slightly greater than 0.85 for the two months of July and August. This value satisfies our need for the local pan coefficient, to convert potential evaporation to lake evaporation. The ice-free period varied between the years of this study, but during all three years no ice remained on the lake after June 23. Evaporation pan records lasted through August 26 during all three years.

Cumulative lake evaporation from June 23 to August 26 was calculated at $168 \mathrm{~mm}, 169 \mathrm{~mm}$, and $117 \mathrm{~mm}$ in 2009 , 2010, and 2011, respectively. These values correspond to average daily lake evaporation rates of $2.6 \mathrm{~mm} / \mathrm{day}$ in 2009 , $2.6 \mathrm{~mm} /$ day in 2010, and $1.8 \mathrm{~mm} /$ day in 2011. Average air temperature (Jun 23-Aug 26) reflects differences in evaporation: $9.3^{\circ} \mathrm{C}$ in 2010 and $8.6^{\circ} \mathrm{C}$ in 2011 (no data for 2009). Evaporation measurements presented here are slightly above the average daily pond evaporation rates of $2.1 \mathrm{~mm} /$ day in 1971, $2.0 \mathrm{~mm} /$ day in 1992, and $2.1 \mathrm{~mm} /$ day in 1993 reported by Kane and Carlson (1973) and Rovansek et al. (1996). Our measurements are generally lower than those reported by Mendez (1997), who measured average evaporation rates for the ponds near Prudhoe Bay at $3.4 \mathrm{~mm} / \mathrm{day}$ in 1994, $3.6 \mathrm{~mm} /$ day in 1995, and $2.3 \mathrm{~mm} /$ day in 1996.

From a hydrological perspective, a net lose of water occurs during the summer because water loss due to evaporation significantly exceeds rainfall. Rainfall minus evaporation (P-E) equaled -96 mm in 2009, -134 mm in 2010, and -89 mm in 2011. Snowdrift meltwater efficiently reduced this difference and diminished precipitation minus evaporation. 


\section{Hydrological response of the lake}

The hydrological response of the lake to snowdrift melt was measured and documented during the two summers of 2010 and 2011. In addition to the snowdrift contribution, the lake water balance is influenced by additions/subtractions from natural snowmelt, rainfall, evaporation, overland flow, and change in surrounding active layer. It is difficult to separate the effect of snowdrift melt on the lake water volume from these other components that contribute to the hydrologic system of the lake. The original intent was to use the lake water volumes variability measured in the control lake as representation of natural conditions in the experimental lake. However, close observations of the water levels showed that there is a constant outflow from the control lake, but nor in the experimental lake. We took an approach of evaluating the change in lake water volume during the two-year experiment against the lake water volume in summer 2009 before installation of the snow fence (baseline data). Results of the weather data analysis summarized in the previous section showed that weather conditions (SWE, rainfall, and evaporation) in the baseline year (2008-2009) were conducive to high natural lake water levels. In contrast, rainfall was below average during the two years of the experiment with the snow fence. Therefore, the years of the experiment represented dry summers and lake conditions that are conducive to low natural lake water levels.

Water levels were continuously recorded with a pressure transducer. To calculate change in lake storage (or volume) from water level, the lake volume-level relationship was established. We first conducted a bathymetry survey on July 28,2009 . The lake water surface area was measured at $21,000 \mathrm{~m}^{2}$, and water volume was calculated at $21,700 \mathrm{~m}^{3}$. Some parts of the lake were very shallow 0.4-0.6 m, but in some places, water depth was more than $2 \mathrm{~m}$ deep, meaning that the deep part of the experimental lake remained unfrozen in winter. Bathymetry data were processed with geographical informational system software (3D Analyst, ArcMap) to interpolate and extrapolate volumes for the range of water levels and obtain the lake volume-level relationship. We used this lake volume-level relationship to convert water levels recorded by the pressure transducer to water volumes.

\section{WATER VOLUME IN THE EXPERIMENTAL LAKE BEFORE AND AFTER SNOW FENCE CONSTRUCTION}

Lake water volumes in summer 2010 and summer 2011 were evaluated against the lake water volume during the baseline summer in 2009 (Figure 13). During the baseline summer, there was a natural decline in water volume due to negative precipitation minus evaporation and to water use by ADOT\&PF. The fast drop in water volume in mid-July 2009 (highlighted in Figure 13 by a thick line) was due to water use by ADOT\&PF to maintain the Dalton Highway. The largest amount of water taken in three years was during summer 2010 (Table 4). Data on water use was recorded by ADOT\&PF and shared with us during the duration of this project. Once this pumped water was added to the observed water volumes, we could obtain reconstructed lake water volumes that reflect lake behavior as if no water had been pumped from the lake during the summer (Figure 14). These reconstructed lake water volumes were used to quantify the effect of the snowdrift. 


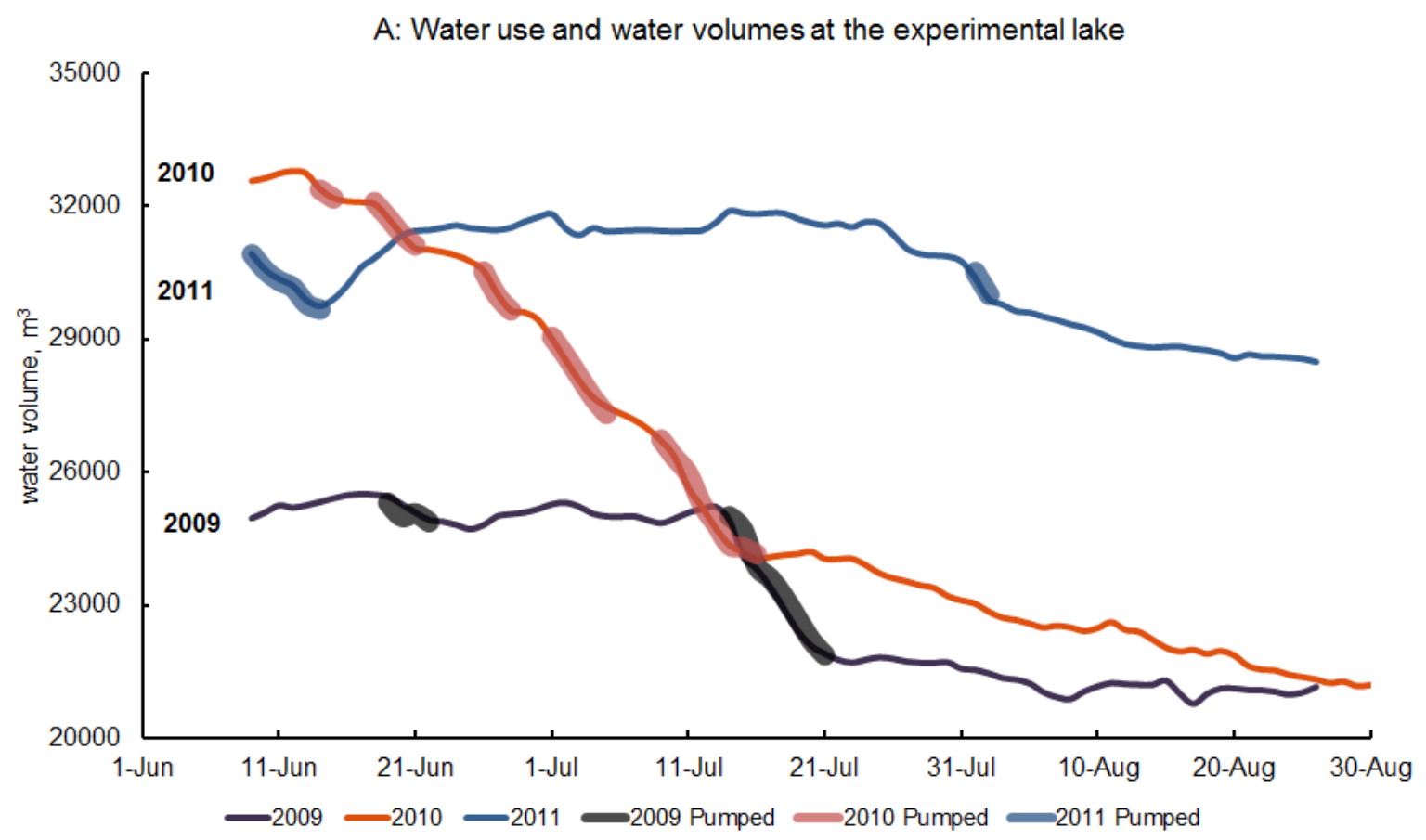

Figure 13. Observed water volume in experimental lake during summers of 2009, 2010, and 2011. Thick highlighted parts of the lines indicate water pumping by ADOT\&PF for maintenance of the Dalton Highway.

Table 4. Experimental lake water volumes $\left(\mathrm{m}^{3}\right)$ and water use $\left(\mathrm{m}^{3}\right)$.

\begin{tabular}{cccc}
\hline & $\mathbf{2 0 0 9}$ & $\mathbf{2 0 1 0}$ & $\mathbf{2 0 1 1}$ \\
\hline Reconstructed water volume on August 26 & 23,914 & 28,858 & $\mathbf{3 0}, 764$ \\
\hline Cumulative water use in summer & 2,756 & $\mathbf{7 , 5 3 2}$ \\
\hline $\begin{array}{c}\text { End-of-summer increase in water volume from } 2009 \\
\text { (including water use) }\end{array}$ & $\mathbf{4 , 9 4 5}$ & $\mathbf{6 , 8 5 1}$
\end{tabular}

Note in Figure 14 that water volumes in the lake were significantly higher during both years of the snowdrift experiment (2010 and 2011). Water volumes remained elevated through the summer, meaning that the lake carried more water into the winter season, when it is needed for construction of ice roads and ice pads. Table 4 shows that the total increase in lake volume by the end of summer was estimated to be $4,945 \mathrm{~m}^{3}(1,306,246$ gallons) in 2010 and $6,851 \mathrm{~m}^{3}(1,809,713$ gallons $)$ in 2011 . These estimates constitute an increase of $21 \%$ and $29 \%$ in comparison with the water volume observed at the end of summer 2009. 


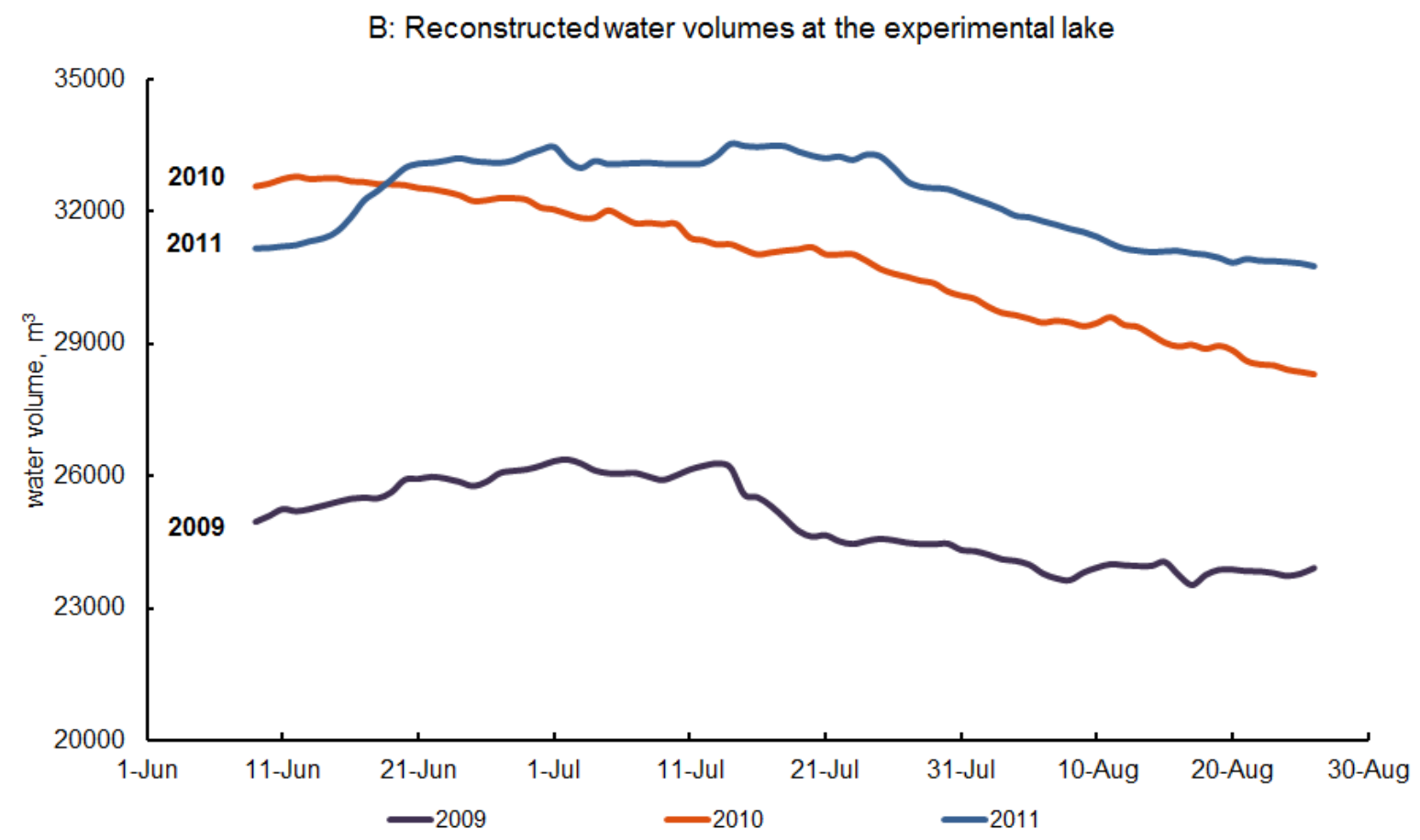

Figure 14. Reconstructed water volume in the experimental lake during summers of 2009, 2010, and 2011.

In comparing these numbers with the water contained in the snowdrift, we can obtain snowdrift water volumes from Table $2-8,850 \mathrm{~m}^{3}$ on April 24,2010 , and $7,026 \mathrm{~m}^{3}$ on April 16, 2011-that correspond to $37 \%$ and $29 \%$ of the end-ofsummer water volume in the lake. A comparison of snowdrift water volumes and total increase in lake volumes indicates a nonlinear response (smaller drift in 2011, but more water in the lake) and the influence of other components of the lake's hydrologic system, such as changes in both surface and subsurface storage between the years.

Water balance accounted for water sources due to rainfall and snowdrift and for water losses due to evaporation and water use. Note that the residual of the water balance includes measurement errors associated with each component and all other water sources and sinks, such as change in subsurface storage. Once we compare the residual with the observed change in lake storage, it is evident that these two numbers are relatively close to each other in 2011, suggesting that rainfall, evaporation, and water use can explain the loss of $88 \mathrm{~mm}$ from $107 \mathrm{~mm}$ in lake levels recorded by the pressure transducer. In 2010, water balance components account for $336 \mathrm{~mm}$ of water loss in the lake, whereas the recorded decrease is $368 \mathrm{~mm}$. In contrast, the water balance residual in 2009 is $-176 \mathrm{~mm}$, and the recorded decrease in lake storage is less than that $(-149 \mathrm{~mm})$. Given the uncertainty in calculating lake evaporation from the evaporation pan, estimating water use from the number of "trucks" filled with water, and not accounting for changes in subsurface storage, it is not surprising to have a discrepancy between the water balance residual and a change in lake storage.

Data presented in this section show that the snowdrift increased lake water volumes in both summer and winter. The estimate of water volume increase presented here should be interpreted as a very conservative estimate, because weather factors (rainfall, evaporation) in summer 2009 were in favor of high lake water volumes and, in contrast, weather factors during the years of this experiment were in favor of low natural lake water volumes. 


\section{LAKE WATER BALANCE}

\section{$\triangle$ RAINFALL}

Red bars represent water gain due to rainfall on the lake surface $(\mathrm{mm})$. Rainfall is summed from June 23 to August 26 each year.

\section{$\checkmark$ EVAPORATION}

Orange bars indicate water loss through evaporation in millimeters. Cumulative evaporation from the lake surface is shown from June 23 to August 26 each year.

\section{SNOWDRIFT CONTRIBUTION}

Water inflow due to drift melt is represented by snow water equivalent (blue bars) distributed over the lake area $(\mathrm{mm})$. This number must be multiplied by the runoff coefficient $(k=0.5)$. Only the contribution after June 23 is shown on the graph. The baseline year, 2009, did not have this component.

\section{$\nabla$ WATER USE}

The Alaska Department of Transportation and Public Facilities uses water from the experimental lake to maintain the Dalton Highway. Water use $(\mathrm{mm})$ from between June 23 and August 26 is represented by brown bars.

\section{RESIDUAL}

Based on numbers from the graph, the residual of the water balance is a negative number each year: $-176 \mathrm{~mm}$ in $2009,-336 \mathrm{~mm}$ in 2010 , and $-88 \mathrm{~mm}$ in 2011.

\section{$\checkmark$ CHANGE IN LAKE STORAGE}

Change in lake storage is calculated from the measurements of water level. These measurements are independent of the water balance components above. The change in lake storage from June 23 to August 26 is a negative number: $-149 \mathrm{~mm}$ in $2009,-368 \mathrm{~mm}$ in 2010 , and $-107 \mathrm{~mm}$ in 2011.

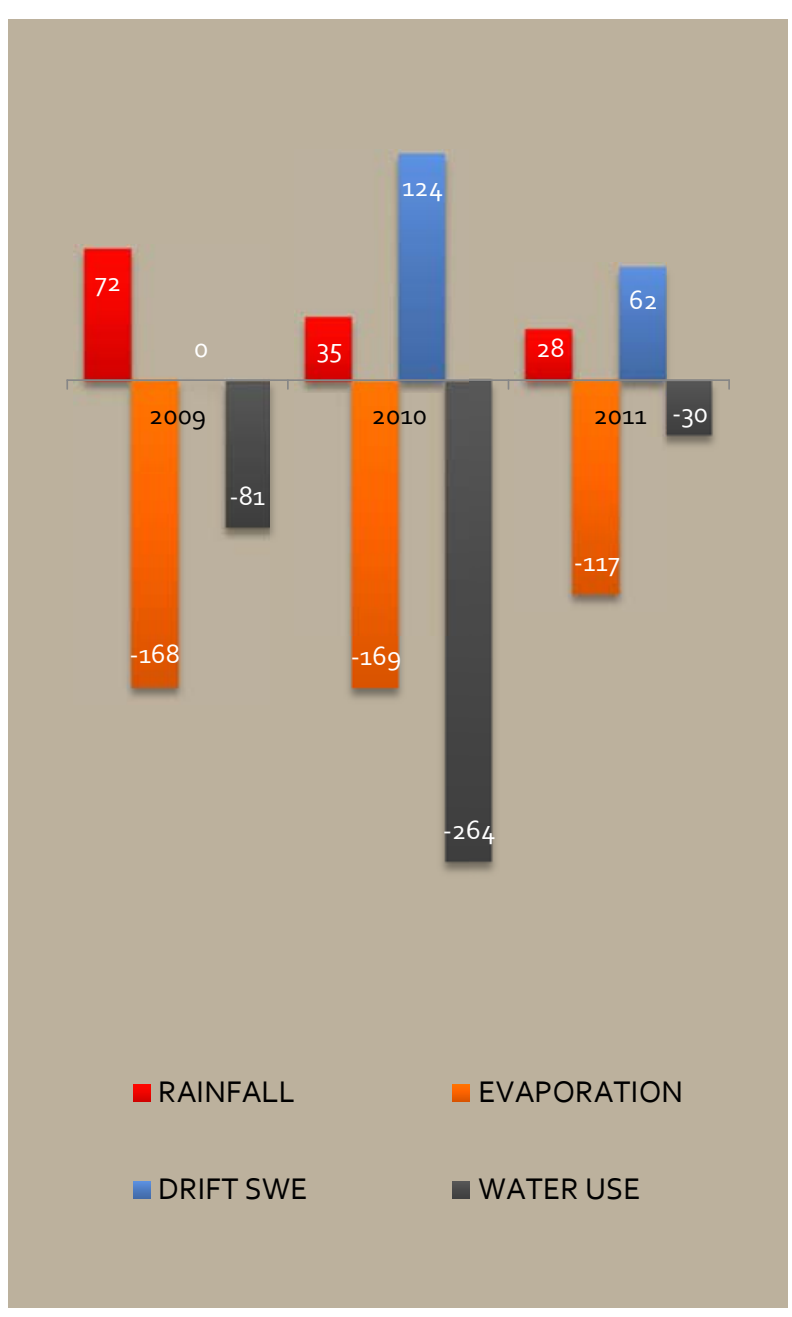

The ice-free period varied between the years, but during all three years, no fast ice remained on the lake after June 23 . During all years, observational data were available through August 26. The water balance components were calculated between June 23 and August 26. 


\section{Water cost}

The intent of this section is to give a basic calculation of snowmelt pricing without attempting an economical analysis. The math is simple: the higher the price of the snow fence is, the higher the price of the generated water will be. In comparison with the contiguous U.S., snow fence costs on the North Slope of Alaska are high. Obtained quotes from local commercial builders ranged from $\$ 4.93$ per sq. $\mathrm{ft}$ (Big Street Contruction, Inc.) to $\$ 7.66$ per sq. $\mathrm{ft}$ (Domestic Endeavors, LCC). These quotes included contruction of the snow fence, but did not involve maintenance or demolition. Tabler (2003) estimated a total cost of snow fence in Wyoming equal to $\$ 1.39$ per sq. $\mathrm{ft}$ of fence frontal area. If we take a conservative approach and proceed with the highest quote, the cost of the $10 \mathrm{ft}$ high and $426 \mathrm{ft}$ long snow fence equals $\$ 25,274$. Thus, water pricing was estimated as a ratio of snow fence cost $(\$ 25,274)$ to end-of-summer increase in water volume from Table 4. In 2011, a cumulative increase in water volume for two years was used (Table 5).

Table 5. Water cost.

\section{0}

2011

\begin{tabular}{ccc}
\hline End-of-summer increase in water volume $\left(\mathrm{m}^{3}\right)$ & 4,945 & 6,851 \\
\hline Water cost per cubic meter & $\$ 5.1$ & $\$ 2.1$ \\
\hline Water cost per thousand gallons & $\$ 19.3$ & $\$ 8.1$
\end{tabular}

Water cost amounts to less than 2 cents per gallon during the first year, and 0.8 cents per gallon for the second year. When these prices are compared with the price of water in populated areas, they appear high. To put this water cost into perspective, one needs to account for added logistical cost in remote arctic areas. For comparison, water cost in Deadhorse was 6.5 cents per gallon in 2010. The cost per gallon of water delivered to the experimental lake (28 miles south of Deadhorse on the Dalton Highway) would be 13 cents.

\section{North Slope Decision Support System}

The snow fence effect was added in the water balance model of the North Slope Decision Support System (NSDSS). A white paper on snow fence incorporation into the NSDSS water budget model is included on the NSDSS website. The white paper provides details on the mathematics of including the snowdrift input. The following citation describes the snow fence option in the water balance model of the NSDSS:

http://nsdss.ine.uaf.edu/NaturalSystemModeling/ WhitePapers/WhitePaper_NSDSS_Lake_Water_Bu dget_Modeling.pdf.

\begin{abstract}
Set your modeling intent in Step 1 too. This informs NSDSS of the type of water budget model you want to make, which helps NSDSS know which model input data to search for.
\end{abstract}

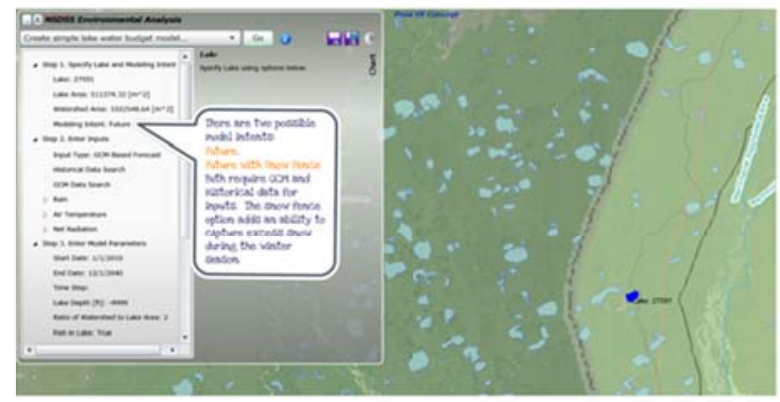




\section{Conclusions}

The Arctic is rich in natural resources. Because of economic conditions and population growth in the United States, exploration of natural resources in the Alaska Arctic has intensified over the last century. The discovery of oil in the Prudhoe Bay area in 1968 has been a catalyst for expanded exploration. This magnified exploration has also driven the need for environmental information in a region dominated by snow, ice, and permafrost. As with many other scientific areas of study in the Arctic, its meteorology and hydrology were not well understood prior to 1970 . Simple processes such as the

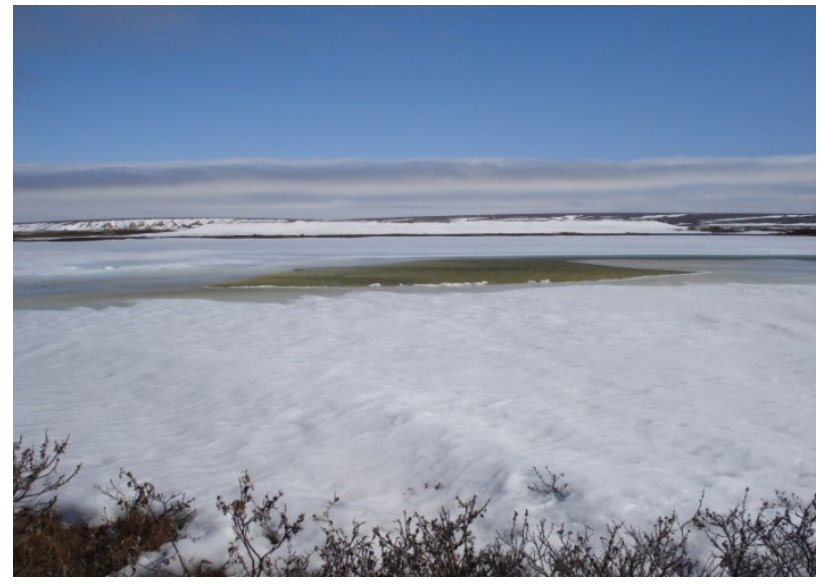
amount of annual precipitation, the partitioning of precipitation into snow water equivalent (SWE) and rainfall, annual river runoff patterns, approximate summer evapotranspiration, spatial and temporal wind patterns, and the thermal regime of permafrost and the active layer were not quantified. However, with the present increase in natural resource exploration, it is imperative that we understand these natural processes so that environmentally sound development decisions can be made.

The Alaska Arctic is characterized by unique elements that must be addressed, such as an extremely cold environment, fragile ecosystems, and continuous permafrost. The Arctic is an area of limited annual precipitation (an Arctic desert), where approximately one-third of the precipitation falls as snow and two-thirds of it fall as rain. The amount of annual precipitation is generally less than $250 \mathrm{~mm}$, with warm season rainfall that increases from the Coastal Plain to the foothills to the mountains. This low amount of precipitation leads to many water resource problems, such as those discussed in this report.

A challenge faced in living or working in the Alaska Arctic is having ample water, particularly during the winter months. The amount of annual precipitation in both SWE and rainfall varies considerably year to year. One of the major uses of water during winter is for construction of ice roads on the tundra, built for traversing with heavy equipment used in exploration. In the summertime, large volumes of water are used for controlling dust on permanent roads. This study examined a technique for increasing the amount of water available during both warm and cold seasons. The technique involves building a snow fence upwind of a lake to enhance lake recharge. Snow fences have proved effective as a tool for trapping snow. In this study, the drift that developed due to the snow fence extended meltwater supply to the lake for one month (until early July). After two winters with the snow fence in place, the average volume of water stored in the experimental lake at summer's end increased by about $25 \%$. The water from delayed snowdrift melt augments the lake water supply available for road maintenance during summer or ice road construction the following winter.

In summary, the results of this study demonstrate that snow fences are an effective way of enhancing the meager amounts of Arctic precipitation so that lake water is replenished and available for use in summer and in winter. 


\section{Graphical Material List}

Figure 1. Map A shows the location of the study area in the state of Alaska. Map B shows the location of the weather station and the experimental and control lakes. Map $C$ indicates the location of the snow fence and sonic sensors in the experimental lake watershed.

Figure 2. Example figure from the completion report showing site conditions before and after the snow fence construction.

Figure 3. The photograph on the left shows a Wyoming-type snow fence near Franklin Bluffs, North Slope of Alaska, constructed for this project (September 2010). The photograph on the right shows a $4 \mathrm{~m}$ tall pole-supported snow fence in Barrow half-hidden under the snowdrift (March 6, 2008). The researcher is standing on top of the snowdrift next to the $5 \mathrm{~m}$ tall instrumentation tower almost buried under the snow.

Figure 4. Actual snow fence location is shown as a green line. Green dots show locations of the three snow depth sonic sensors (10 $\mathrm{m}, 16 \mathrm{~m}$, and $34 \mathrm{~m}$ away from the fence).

Figure 5. Left panel shows SnowModel simulation domain and proposed snow fence locations (line A and line B). Simulated snow water equivalent (SWE) for the proposed snow fence location $A$ is shown on the central panel. Simulated snow water equivalent (SWE) 2008 for the proposed snow fence location B is shown on the right panel.

Figure 6. Top panel shows location of the snow depth sensors on the lee side of the snow fence. Bottom pictures show locations of snow fence and instrumentation relative to the gravel pit. These photographs were taken shortly after the snow fence installation on September 28, 2009.

Figure 7. Snow depth measured by three sonic sensors SR50, located at 10, 16 and $34 \mathrm{~m}$ perpendicular to the snow fence.

Figure 8. An example of a typical snow deposition event (SDE) at Franklin Bluffs, recorded by snow depth sensors. Within just several hours, a few meters of snow had been deposited at the fence. The reported wind speed is averaged over one hour.

Figure 9. Schematic diagram showing an approach to calculating daily snowdrift melt based on records from the three SR50 sensors.

Figure 10. Depletion curve of snowdrift and natural snowpack in 2010 and in 2011.

Figure 11. Long-term observation of end-of-winter snow water equivalent at Franklin Bluffs, 2000-2011.

Figure 12. Cumulative summer rainfall from June 6 to August 31 at Franklin Bluffs. Bias-correction was applied to daily rainfall data.

Figure 13. Observed water volume in the experimental lake during summers of 2009, 2010, and 2011. Thick highlighted parts of the line indicate water pumping by ADOT\&PF for maintenance of the Dalton Highway.

Figure 14. Reconstructed water volume in the experimental lake during summers of 2009, 2010, and 2011. 


\section{References}

Arp, C.D., M.S. Whitman, B.M. Jones, R. Kemnitz, G. Grosse, and F.E. Urban, 2012. Drainage network structure and hydrologic behavior of three lake-rich watersheds on the Arctic Coastal Plain, Alaska. Arctic, Antarctic, and Alpine Research, 44(4): 385-398.

Bowling, L.C., D.L. Kane, R.E. Gieck, L.D. Hinzman, and D.P. Lettenmaier, 2003. The role of surface storage in a lowgradient Arctic watershed. Water Resour. Res., 39(4): 1087, doi:10.1029/2002WR001466.

Brown, R.H., 1983. Snow Fences: Then and Now. J. Cultural Geog., 4(1): 87-98.

Dingman, L.S., 2008. Physical Hydrology, Waveland Pr Inc, 656 pp.

Hinkel, K.M. and J.K. Hurd, Jr., 2006. Permafrost destabilization and thermokarst following snow fence installation, Barrow, Alaska, U.S.A. Arctic, Antarctic and Alpine Research, 38(4): 530-539.

Hinzman, L.D., M.R. Lilly,, D.L. Kane, D.D. Miller, B.K. Galloway, K.M. Hilton, and D.M. White, 2006. Physical and Chemical Implications of Mid-Winter Pumping of Tundra Lakes-Arctic Slope, Alaska. Water and Environmental Research Center, University of Alaska Fairbanks, Report INE/WERC 06.15, Fairbanks, AK.

Jairell, R.L. and R.A. Schmidt, 1990. Snow fencing near pit reservoirs to improve water supplies. Proceedings of the $58^{\text {th }}$ Western Snow Conference, Sacramento, CA, April 17-19, 1990, 156-159.

Kane, D.L. and R.F. Carlson, 1973. Hydrology of the Central Arctic River Basins of Alaska. Institute of Water Resources, University of Alaska Fairbanks, Report No. IWR-41.

Kane, D.L., L.D. Hinzman, R.E. Gieck, J.P. McNamara, E.K. Youcha, and J.A. Oatley, 2008. Contrasting extreme runoff events in areas of continuous permafrost. Arctic Alaska. Hydrology Research, 39(4): 287-298.

Kohler, M.A., T.J. Nordenson, and W.E. Fox, 1955. Evaporation from pans and lakes. U.S. Weather Bureau, Research paper 38, $20 \mathrm{pp}$.

Liston, G.E. and M. Sturm, 2004. The role of winter sublimation in the Arctic moisture budget. Nordic Hydrology, 35 : 325-334.

Liston, G.E. and K. Elder, 2006. A distributed snow-evolution modeling system (SnowModel). J. Hydrometeorology, 7: 1259-1276.

McFadden, T. and C. Collins, 1978. Fresh Water Supply for a Village Surrounded by Salt Water, Point Hope, Alaska. CRREL, Hannover, Special report.

Mendez, J., 1997. Evapotranspiration from a Wetland Complex on the Arctic Coastal Plain of Alaska. Master's thesis, University of Alaska Fairbanks.

Rovansek, R.J., L.D. Hinzman, and D.L. Kane, 1996. Hydrology of a tundra wetland complex on the Alaskan Arctic coastal plain, U.S.A. Arctic and Alpine Research, 28(3): 17 pp.

Seward Weekly Gateway, 1909. Alaska Miners Store Snow. Seward Weekly Gateway, April 10, 1909, p2C2.

Shulski, M. and G. Wendler, 2007. Climate of Alaska, University of Alaska Press.

Slaughter, C.W., 1974. Seasonal snowpack research and management in Alaska. Fairbanks: Alaska Division, USA, CRREL. 
Slaughter, C.W., M. Mellor, P.V. Sellmann, J. Brown, and L. Brown, 1975. Accumulating Snow to Augment the Fresh Water Supply at Barrow, Alaska. CRREL, Hannover, Special report.

Stuefer, S.L., 2011. Using snow fences to augment fresh water supplies in the Arctic Lakes, Proceedings of the Arctic Technology Conference, Houston, Texas, February 5-7, 2011.

Stuefer, S.L. and M. Sturm, 2012. Quantifying snow transport using snow fences and sonic sensors. Proceedings of the International Snow Science Workshop, Anchorage, Alaska, USA, September 16-21, 2012.

Sturges, D.L., 1989. Evaporation and seepage from a livestock reservoir equipped with a snow fence for water recharge. Proceedings of the $57^{\text {th }}$ Western Snow Conference, April 18-20, 1989, Fort Collins, Colorado, pp. 9-20.

Sturges, D.L., 1992. Streamflow and sediment transport responses to snow fencing a rangeland watershed. Water Resources Research, 28(5): 1347-1356.

Sturm, M. and S.L. Stuefer, 2013. Windblown flux rates derived from drifts at Arctic snow fences. Journal of Glaciology, 59(213): 21-34, doi: 10.3189/2013JoG12J110

Tabler, R.D., 1980. Geometry and density of drifts formed by snow fences. J. Glaciol., 26: 405-419.

Tabler, R.D., 1994. Design Guidelines for the Control of Blowing and Drifting Snow. Strategic Highway Research Program.

Tabler, R.D., 2003. Controlling Blowing and Drifting Snow with Snow Fences and Road Design. Final Report. Tabler and Associates, Niwot, Colorado.

Tabler, R.D. and D.L. Sturges, 1986. Watershed test of a snow fence to increase streamflow: Preliminary results. Proceedings of the American Water Resources Association, Symposium: Cold Regions Hydrology (Fairbanks, AK; July 1986) Proceedings, Technical Publication Series TPS-86-1, pp. 53-61.

Winter, T.C., 1981. Uncertainties in estimating the water balance of lakes. Water Resources Bulletin, $17(1): 34$ pp. 


\section{List of Acronyms and Abbreviations}

$\begin{array}{ll}\text { ADOT\&PF } & \text { Alaska Department of Transportation and Public Facilities } \\ \text { CRREL } & \text { Cold Resgion Research and Engineering Laboratory } \\ \text { CSU } & \text { Colorado State University } \\ \text { DGPS } & \text { Differential Global Positioning System } \\ \text { DNR } & \text { Department of Natural Resources } \\ \text { DOE } & \text { Departement of Energy } \\ \text { NETL } & \text { National Energy Technology Laboratory } \\ \text { NSB } & \text { North Slope Borough } \\ \text { NSDSS } & \text { North Slope Decision and Support System } \\ \text { QA/QC } & \text { Quality Assessment and Quality Control } \\ \text { SR50 } & \text { Sonic Ranging Sensor by Campbell Scientific } \\ \text { SWE } & \text { Snow Water Equivalent } \\ \text { UAF } & \text { University of Alaska Fairbanks }\end{array}$

